\title{
Rapid and accurate measurement methods for determining soil hydraulic properties: A review
}

\author{
Mirko Castellini $^{1 *}$, Simone Di Prima ${ }^{2,3}$, David Moret-Fernández ${ }^{4}$, Laurent Lassabatere ${ }^{3}$ \\ ${ }^{1}$ Council for Agricultural Research and Economics-Research Center for Agriculture and Environment (CREA-AA), Via C. Ulpiani 5, \\ 70125 Bari, Italy. \\ ${ }^{2}$ Department of Agricultural Sciences, University of Sassari, Viale Italia, 39, 07100 Sassari, Italy. \\ ${ }^{3}$ Univ Lyon, Université Claude Bernard Lyon 1, CNRS, ENTPE, UMR 5023 LEHNA, F-69518, Vaulx-en- Velin, France. \\ ${ }^{4}$ Departamento de Suelo y Agua, Estación Experimental de Aula Dei, Consejo Superior de Investigaciones Científicas (CSIC), PO Box \\ 13034, 50080 Zaragoza, Spain. \\ * Corresponding author. Tel.: +39-080-5475039. E-mail: mirko.castellini@crea.gov.it
}

\begin{abstract}
The determination of soil hydraulic properties is important in several environmental sciences but may be expensive and time consuming. Therefore, during the last decades, a great effort has been made in soil sciences to develop relatively easy, robust, and inexpensive methods for soil hydraulic characterization. In this manuscript, we reviewed and discussed different infiltrometer techniques in light of the available experimental applications. More specifically, we considered the simplified falling head (SFH) infiltrometer technique and the single-ring infiltration experiment of the Beerkan type. Concerning this latter method, we considered different algorithms for data analysis: two simplified methods based on the analysis of transient (TSBI) and steady (SSBI) Beerkan infiltration data, and the Beerkan Estimation of Soil pedoTransfer parameters algorithm (BEST), that allows to estimate the soil characteristics curves, i.e., the soil water retention curve and hydraulic conductivity functions. For a given method, after dealing briefly theory and practice, available literature references were reported to account for specific applications in order to provide findings on method validation and application. With the aim to provide practical information on available tools for a simpler application of the reviewed methods, several video tutorials were reported to show i) how to conduct correctly field experiments and ii) how to calculate saturated hydraulic conductivity or soil hydraulic functions using user-friendly tools for data analysis. Finally, details on a new automated single-ring infiltrometer for Beerkan infiltration experiments (i.e., construction, assembly and field use) were presented.
\end{abstract}

Keywords: SFH technique; Beerkan method; BEST-procedure; Saturated hydraulic conductivity; Soil hydraulic properties; Infiltrometer.

\section{INTRODUCTION}

Determination of soil hydraulic properties is important for many areas of environmental research. In addition to soil science, in fact, several environmental sciences, e.g., agronomy, ecology or geography, often need in-depth analysis on the soilplant-atmosphere system to better investigate biophysical processes (Castellini and Iovino, 2019; Donatelli, 2014). Simulation of the soil-plant-atmosphere continuum (Shelia et al., 2018) and optimization of water use efficiency for cropping systems (Rallo et al., 2018), study of the dynamics of water and solutes in porous media (Sidoli et al., 2016), impacts of soil management on greenhouse gases emissions (Ferrara et al., 2017), and the partitioning of rainfall into infiltration and excess runoff, and impacts on soil erosion (Biddoccu et al., 2016), represent common examples of significant agro-environmental applications.

A relatively high number of conventional techniques for soil hydraulic properties estimation, both in field and laboratory, are available to carry out an accurate characterization of the soil hydraulic properties (Angulo-Jaramillo et al., 2016). Standard field methods such as uncased boreholes or ring permeameters and tension infiltrometers, for example, were widely used to measure saturated and unsaturated hydraulic conductivity and to conduct specific investigations on agricultural soils (AnguloJaramillo et al., 2016). Several examples of saturated and unsaturated hydraulic conductivity determinations are available for specific applications carried out in agricultural (Ciollaro and Lamaddalena, 1998), forest (Braud et al., 2017; Pirastru et al., 2014), or marginal (Verbist et al., 2013) soils. However, these methods may present some issues, especially for nonspecialized users in soil science or for spatially distributed applications, owing to a relatively high complexity (i.e., data analysis), and application difficulties normally encountered in the field (for example, for an optimal preparation of the measurement site). Consequently, in recent years, a great effort has been made in soil science to develop relatively easy, robust, and inexpensive methods for soil hydraulic characterization (refer to Angulo-Jaramillo et al., 2016, for a review).

In this manuscript, we focus on the simplest methods for soil hydraulic characterization, including the Simplified Falling Head (SFH) technique (Bagarello et al., 2004), the Simplified methods based on a Beerkan Infiltration (Transient, TSBI, and Steady state SSBI, methods) (Bagarello et al., 2014a; Bagarello et al., 2017a) for rapid determination of soil field-saturated hydraulic conductivity, and the Beerkan Estimation of Soil pedoTransfer (BEST) parameters procedure (Lassabatere et al., 2006) for a complete soil hydraulic characterization. Among the available simplified methods, they were selected because they provided evidence of reliability and theoretical robustness. For these methods, we reported literature references to present the theory and practice. For the latter, various applications were summarized in a table, in order to show aims and highlights of the researches, while specific applications were grouped to 
discuss some hydrological and agro-environmental research topics (i.e., assessment of spatial and temporal variability of saturated hydraulic conductivity, soil sealing and crust assessment, soil use impact on physical and hydraulic properties, soil physical quality assessment). This is relevant to guide the reader towards possible agro-environmental applications and to take stock on the state-of-the-art on simple water infiltration techniques. For this purpose, ISI papers were generally selected from Scopus database, and about eighty representative manuscripts were considered. For the four reference papers (BEST, SFH, TSBI, SSBI), some statistics (i.e., citations, usage and captures) were preliminary reported and discussed using Scopus (e.g., PlumX Metrics) or Google Scholar database, in order to highlight the interest of the scientific community. These statistics could be useful for quantifying trends of future interest. The final section of this manuscript provides practical information on available tools for a simpler application of the selected methods. At this aim, we reported links to video tutorials (VTs) showing how to conduct correctly field experiments and how to calculate saturated hydraulic conductivity or soil hydraulic functions using user-friendly tools for data analysis (i.e., worksheets or free GUI tools). Finally, the final section suggests research topics that are still open and/or deserve to be further investigated to improve the reliability of reviewed methods.

\section{SPREAD OF METHODS: CITATIONS, USAGE AND CAPTURE STATISTICS TO QUANTIFY THE IMPACT ON THE SCIENTIFIC COMMUNITY}

The summary statistics for the works reviewed in this paper may be considered valid until September 2020 and completes the previous study by Angulo-Jaramillo et al. (2019). The BEST method (i.e., BEST-Slope) was largely cited (177 times according to Scopus database and 304 according to Google scholar). Relatively lower impact had SFH (93 and 173 according to Scopus and Google scholar, respectively), TSBI (28 and
39) and SSBI (20 and 21) (Figure 1a). However, the number of citations depends on the date of publications of methods. The citation benchmark from Scopus platform standardizes the number of citations accounting for the date of publication and the type of documents and assign to any paper its position in terms of percentages. The citation benchmark suggests percentile values between 73 (TSBI) and 90 (SSBI) (Figure 1b). The relative high interest of the most recent work, namely SSBI, for example, is also confirmed when considering the usage indicator (Figure 1c). Usage is a way to report the real usage and utilization of the methods (or article findings for any type of article). The highest usage was reported for the BEST method (Figure 1c). Moreover, since "capture" statistic (Figure 1d) indicates that someone wants to come back on the BEST work in almost 477 cases, we may conjecture that BEST is more likely to be disseminated and applied, followed by SFH (162), SSBI (120) and TSBI (88) (Figure 1d).

\section{SIMPLIFIED FALLING HEAD TECHNIQUE}

The simplified falling head, SFH technique (Bagarello et al., 2004) consists of quickly pouring a known volume of water, $V\left(\mathrm{~L}^{3}\right)$, on the soil confined inside a ring inserted at a fixed depth into the soil, $d(\mathrm{~L})$ and measuring the time, $t_{a}(\mathrm{~T})$, necessary for the poured volume to fully seep through to the surface area, $A\left(\mathrm{~L}^{2}\right)$. Taking into account that the considered infiltration model applies to one-dimensional flow, the depth of the wetting front, $d_{w}(\mathrm{~L})$, at the end of the SFH experiment, should be less than or equal to $d$, and should not emerge from the bottom ring edge. In practice, the volume of water $V$ should be less than or equal to the volume of voids, $V_{p}\left(\mathrm{~L}^{3}\right)$, within the bulk soil volume confined by the ring, $V_{c}\left(\mathrm{~L}^{3}\right)$ :

$$
V \leq V_{p}=V_{c} \Delta \theta=d A \Delta \theta
$$

where $\Delta \theta\left(\mathrm{L}^{3} \mathrm{~L}^{-3}\right)$ is the difference between the saturated $\theta_{s}\left(\mathrm{~L}^{3} \mathrm{~L}^{-3}\right)$, and initial, $\theta_{i}\left(\mathrm{~L}^{3} \mathrm{~L}^{-3}\right)$, soil volumetric water content.
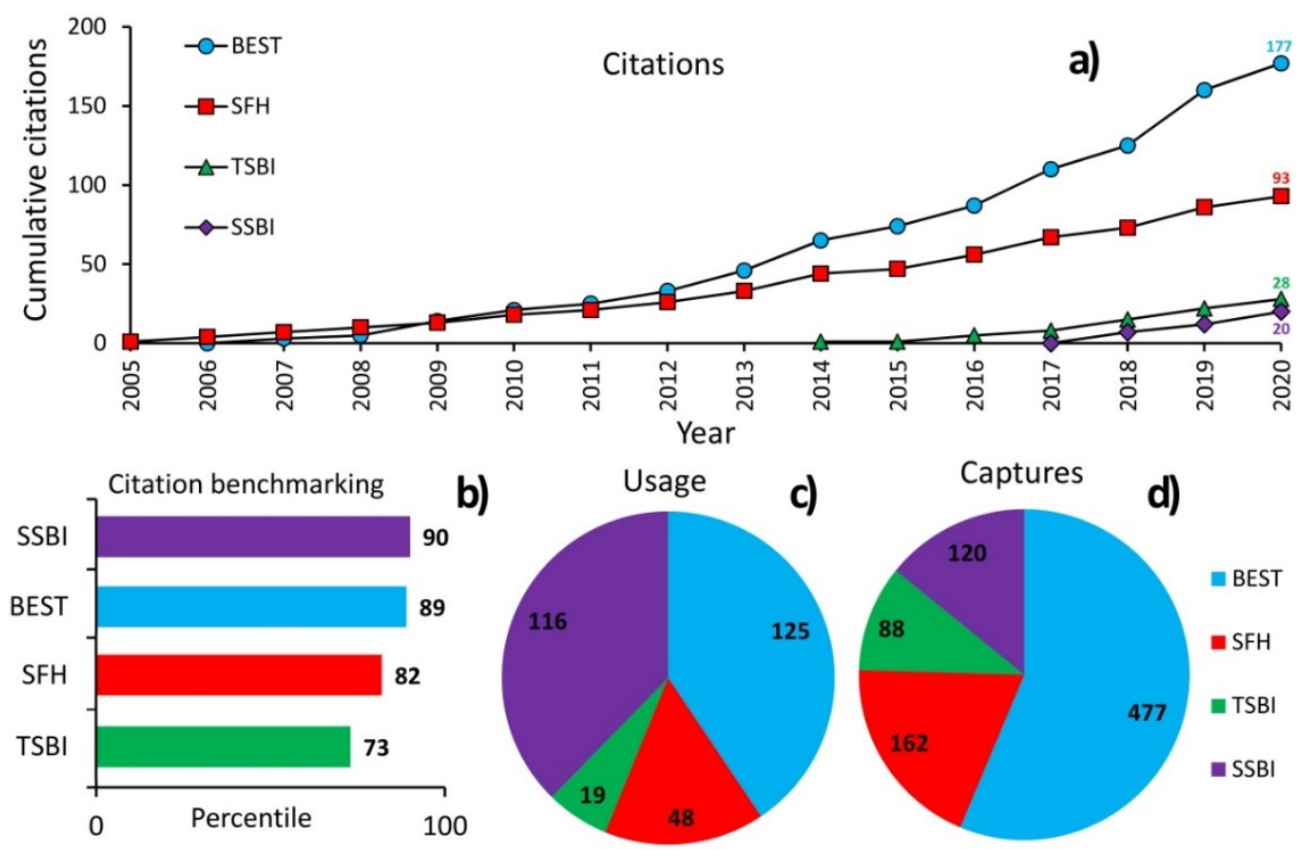

Fig. 1. Spread and impact on the scientific community of BEST, SFH, TSBI and SSBI methods: a) number of citations (Scopus database), b) citation benchmarking (shows how a given work with similar types of works compares in terms of citation, with time normalization), c) usage (signals if anyone is reading the articles or otherwise using the research) and d) captures (indicates that someone wants to come back to the work). The citation benchmarking, usage and captures metrics were provided by Plum Analytics. 
The $K_{s}$ value is determined by a one-dimensional, transient, falling-head infiltration process, based on the analysis by Philip (1992), as already suggested by Bagarello et al. (2004):

$K_{s}=\frac{\Delta \theta}{(1-\Delta \theta) t_{a}}\left[\frac{D}{\Delta \theta}-\frac{\left(D+\frac{1}{\alpha^{*}}\right)}{(1-\Delta \theta)} \ln \left(1+\frac{(1-\Delta \theta) D}{\Delta \theta\left(D+\frac{1}{\alpha^{*}}\right)}\right)\right]$

where $D=V / A(\mathrm{~L})$ is the depth of water corresponding to $V$ and $\alpha^{*}\left(\mathrm{~L}^{-1}\right)$ is a soil texture/structure parameter called sorptive number. According to the original procedure reported by Bagarello et al. (2004), two undisturbed soil cores (usually $5 \mathrm{~cm}$ in height by $5 \mathrm{~cm}$ in diameter) need to be sampled at the 0 to 5 and 5 to $10 \mathrm{~cm}$ depth before the measurements to determine the dry soil bulk density, $\rho_{b}\left(\mathrm{M} \mathrm{L}^{-3}\right)$, and the initial water content, $\theta_{i}$. $\theta_{s}$ is estimated from $\rho_{b}$ and considering a soil particle density of $2.65 \mathrm{~g} \mathrm{~cm}^{-3}$ (Bagarello et al., 2004; Bagarello et al., 2014b). A choice of the most suitable $\alpha^{*}$ parameter may be done on the basis of the textural and structural soil characteristics, as it is indicative of the relative importance of the gravity and capillarity components during steady flow (Bagarello et al., 2014b). Figure 2 summarizes the $\alpha^{*}$ values suggested by Elrick and Reynolds (1992) for five different soil texture-structure categories (i.e., the soil capillarity categories).

A few simple basic rules should be respected to properly conduct SFH experiments in the field. Infiltration surface should be smoothed and carefully cleaned with a mason's trowel to remove residuals, vegetation and soil crust. When present, plants should not be pulled out but cut at the base with a scissor, thus leaving the roots into the soil while minimizing soil disturbance. Several ring diameters may be used for SFH experiments, but most of the research works used dimensions between 15 to $30 \mathrm{~cm}$ for internal diameters (Bagarello and Sgroi, 2007; Bagarello et al., 2014c; Castellini et al., 2015). If the contact between the inner wall of the cylinder and the soil appear locally poor, the flat soil surface should be restored with a pencil or a trowel tip; this foresight prevents water leakage or preferential flow at the edge of the ring (Angulo-Jaramillo et al., 2016). Finally, water pouring should be quite fast (approximately $5 \mathrm{~s}$ ) but should not result in soil compaction or soil surface disturbance; consequently, it is advisable to break the water flow on the operator's fingers (Bagarello et al., 2014b) or, alternatively, on a sponge (see video VT1 in Table S1). Many of these precautions are common, and necessary for most applications, including the following experimental procedures.

\subsection{SFH validation}

Validation of SFH technique was made essentially by comparing the SFH method with the single-ring pressure infiltrometer (PI) and constant head permeameter (CHP) methods, and considering a wide range of textured soils, from fine to coarse (Figure 3). In particular, available comparisons between $K_{S^{-}}$ $S F H$ and $K_{s}-P I$ showed a substantial equivalence between methods for relatively coarse soils (Bagarello and Sgroi, 2007; Bagarello et al., 2006) and a tendency to slightly overestimate $\left(K_{s}-S F H>K_{s}-P I\right)$ for the finer ones (Bagarello et al., 2012) (Figure 3). Although SFH and PI methods provide a $K_{s}$ estimation that accounts for a one-dimensional and three-dimensional infiltration process, respectively, starting from relatively unsaturated soil conditions, possible $K_{s}-S F H$ overestimations can be partially attributed to the lower infiltration time of $\mathrm{SFH}$ compared to PI, since it is expected that longer running times of infiltration experiments may promote swelling phenomena (i.e.,

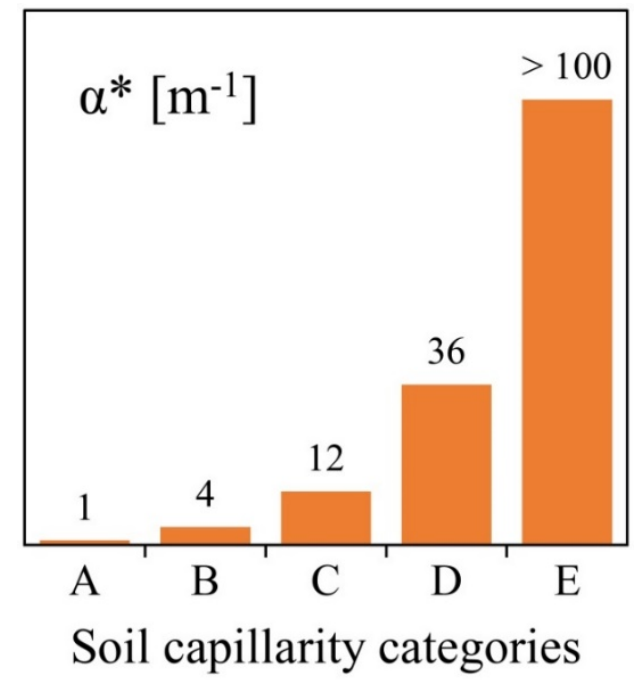

Fig. 2. Values of $\alpha^{*}$ parameter for a given textural and structural soil characteristic (Elrick and Reynolds, 1992; Reynolds and Lewis, 2012). (A) $\alpha^{*}=1 \mathrm{~m}^{-1}$ for soils with very strong capillarity (i.e., compacted soils, structureless, clayey or silty materials such as landfill caps and liners, lacustrine or marine sediments); (B) $\alpha^{*}$ $=4 \mathrm{~m}^{-1}$ for soils with strong capillarity (i.e., porous materials that are both fine textured and massive; includes unstructured clayey and silty soils, as well as very fine to fine structureless sandy materials); (C) $\alpha^{*}=12 \mathrm{~m}^{-1}$ for soils with moderate capillarity (i.e., most structured and medium textured materials; includes structured clayey and loamy soils, as well as medium single grain sands; this category is generally the most appropriate for agricultural soils); (D) $\alpha^{*}$ $=36 \mathrm{~m}^{-1}$ for soils with week capillarity (i.e., coarse and gravelly single-grain sands; may also include some highly structured soils with large and/or numerous cracks and biopores); (E) $\alpha^{*} \geq 100 \mathrm{~m}^{-1}$ for soils with negligible capillarity (i.e., gravels or very coarse sand containing negligible amounts of sand, silt or clay).

especially for clay soils), thus reducing soil macroporosity (Bagarello et al., 2014c). In this regard, Bagarello et al. (2014c), investigated a wide range of agricultural soils and demonstrated that differences between $K_{s}-S F H$ and $K_{s}-P I$ ranged within a factor $2.6-27$ for relatively coarse soils, and a factor 3.2-192.3 for fine textured soils. Therefore, literature references suggest that such remarkable differences can be mostly explained by the negligible SFH effect on soil surface (i.e., no compaction), and this is explained because of the single water volume, which is gently poured on the infiltration surface from a small height, may ensure a negligible disturbance of the soil surface (Bagarello et al., 2014c). In addition, the small volume of the sampled soils decreases the probability of sampling different layers and/or types of soil surfaces at the same time.

Additional experimental factors investigated for SFH validation were the ring size and the source shape impact on $K_{s}$ estimation. Multiple comparisons with rings of different diameters within the range 5-32 cm were tested by Bagarello et al. (2012) and by Khodaverdiloo et al. (2017), respectively. According to these authors, larger rings should be used with the SFH technique, especially when poorly permeable soils are sampled. On the other hand, larger infiltration surfaces can provide greater confidence to take a more representative samples (Bagarello et al., 2020), and include macropore networks (Bagarello et al., 2010a). The increase in the representativeness of the $K_{s}$ estimates, using larger rings is well known in literature. For instance, Figure 4 depicts, for a clay soil, the impact of the ring diameter on $K_{s}$ estimation, with a significantly lower uncertainty 
SFH a)
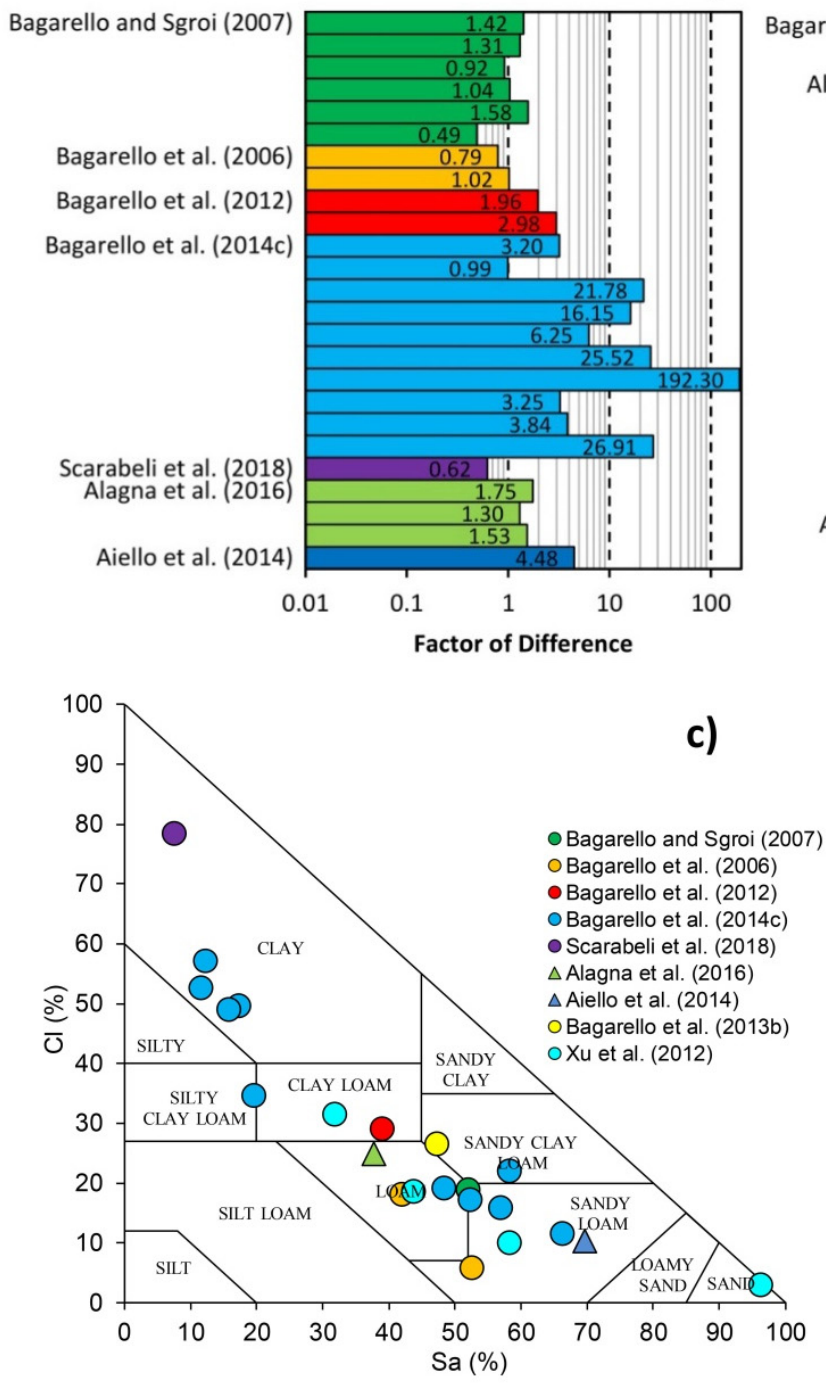

BEST

b)

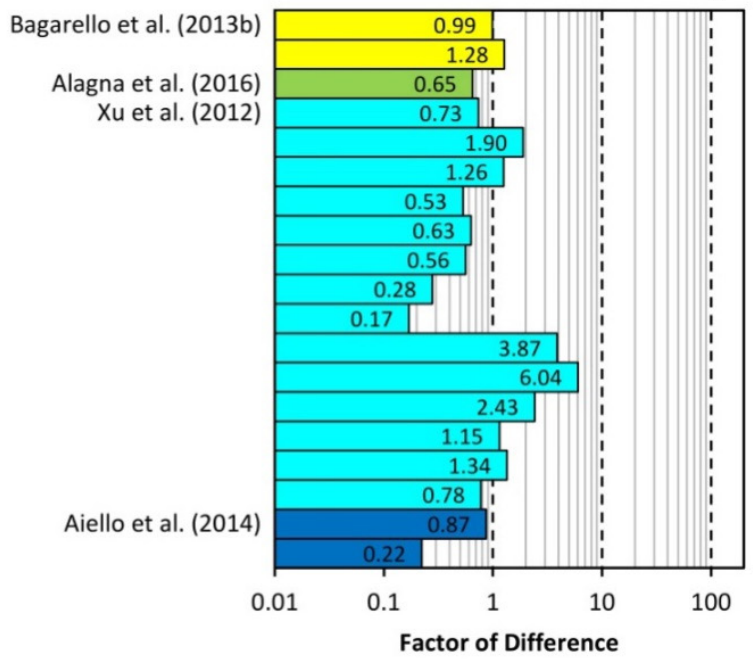

d)

Fig. 3. Ratio between mean values of $K_{s}$ obtained by SFH (a) or BEST (b) against independent methods. The USDA soil texture classes and the methods applied for the validation are also shown (c and d, respectively). Note that for Bagarello et al. (2013b), only the mean value of soils texture is reported. Methods references: OPD-TPD (Reynolds and Elrick, 1990); CHP (e.g., Klute and Dirksen, 1986); BB (Nimmo et al., 2009); BEST (Bagarello et al., 2014e; Lassabatere et al. 2006; Yilmaz et al., 2010); Wi and W2 (Wu et al., 1999).

when using a ring of $30 \mathrm{~cm}$ instead of $15 \mathrm{~cm}$ (Bagarello et al., 2020). In addition to the apparatus size, the influence of the infiltration source shape, i.e., circle or square, was investigated by Bagarello et al. (2017b), and the latter shape could represent a good way to characterize the saturated soil of an area of interest (for example, square or rectangular surfaces) and as rectangular shapes may be more practical to produce. Different methods were used to estimate $K_{s}$ for PI and SFH techniques. Results showed comparable $K_{s}-S F H$ estimations using circular or square sources (i.e., with differences in $K_{s}$ estimations lower than a factor 1.2), suggesting that simple infiltrometer experiments can also be carried out using square sources. Note that the last statement addresses the case of well inserted devices for $1 \mathrm{D}$ infiltration monitoring. When $3 \mathrm{D}$ is involved, the source should remain circular for the mathematical treatment of the data (e.g., Smettem et al., 1994).

A comparison with lab methods, i.e., $K_{s}-S F H$ vs. $K_{s}-C H P$, showed a substantial equivalence under certain circumstances (e.g., characterization of traffic and non-trafficked clay soils studied by Scarabeli et al. (2018)). Because the constant head permeameter is a standard method still widely applied for many agro-environmental applications, results suggested that SFH could represent a viable alternative for a simple and accurate estimation of $K_{s}$ in field (Scarabeli et al., 2018). Discrepancies at most equal to a factor of 1.8 or 4.5 were observed by Alagna et al. (2016) or Aiello et al. (2014), respectively, thus confirming the results of Scarabeli et al. (2018). Figure 3a depicts the comparison of estimates of the references discussed above.

Finally, the soundness of $K_{s}-S F H$ estimation was also checked by Agnese et al. (2011) for pasture and forest soils. As expected by theory, results showed that, for a given sampled area, i) mean $K_{s}-S F H$ values increased with the mean effective porosity (i.e., $K_{s}$ increased with the increasing of macroporosity), ii) $K_{s}-S F H$ increased with the increase of soil organic matter content and iii) decreased with the increase of dry soil bulk density. Therefore, the conclusion drawn by the authors is that the SFH technique can be used to sample large areas and to obtain plausible $K_{s}$ values, defining physically reasonable relationships with other independently measured soil properties. Consequently, in the following section several examples were reported to account for possible agro-environment applications, and representative selected investigations analyzed in detail. 


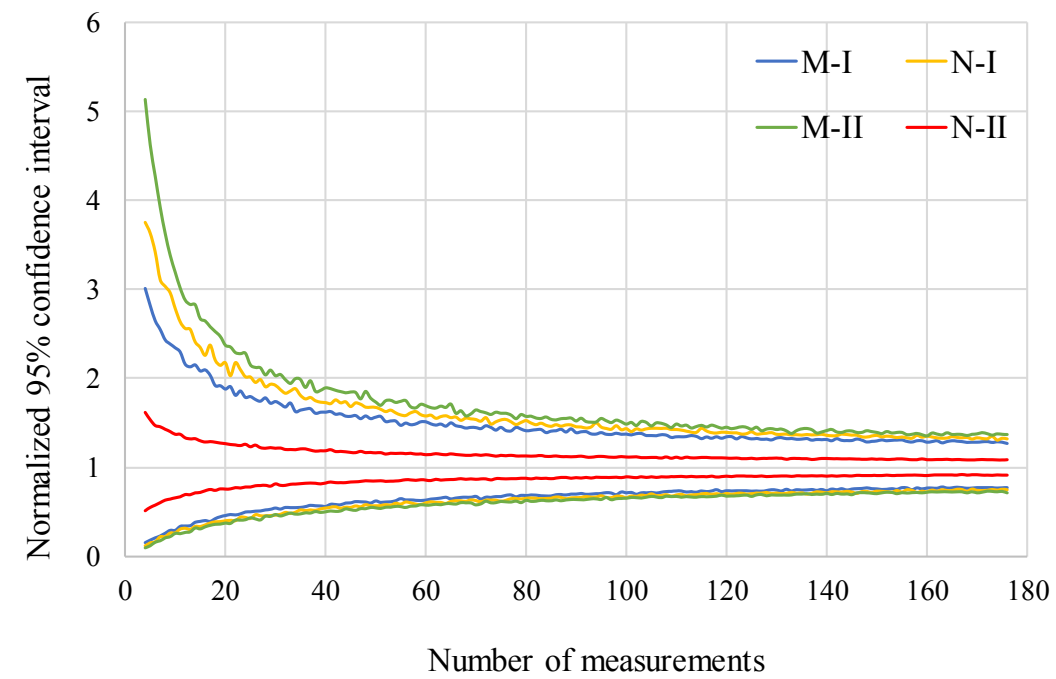

Fig. 4. Impact of the ring diameter, i.e., $15 \mathrm{~cm}(\mathrm{M}-\mathrm{I}, \mathrm{M}-\mathrm{II}, \mathrm{N}-\mathrm{I})$ or $30 \mathrm{~cm}$ (N-II) on normalized $95 \%$ confidence intervals of saturated soil hydraulic conductivity geometric mean obtained applying the SFH method. M and N indicate adjacent plots sampled in two, I and II, sampling dates (adapted from Bagarello et al., 2020).

\subsection{SFH application}

Overall, twenty-two papers were selected to illustrate the application of the SFH method. However, although most of the selected references had various experimental purposes, it was possible to split them into two main groups: i) several applications for saturated hydraulic conductivity determination and ii) spatio-temporal variability of $K_{s}$ (Table 1). In fact, as SFH is generally suggested to properly investigate spatial and temporal variability of $K_{s}$, the researches aimed at deepening this topic have been discussed in more details in section (3.2.2).

\subsubsection{Saturated soil hydraulic conductivity determination by the SFH technique}

Fourteen investigations were summarized to describe SFHapplications in several agro-environments. These works were mainly addressed to the study of i) the impact of soil use on soil physical and hydraulic properties, ii) pollutant transfer in agricultural and forestry environments or iii) runoff-erosion processes. Therefore, aims and highlights of selected studies were reported in Table 1.

\subsubsection{Assessment of spatial and temporal variability of $K_{s}$ by $\mathrm{SFH}$}

Saturated soil hydraulic conductivity, $K_{s}$, is a soil property highly variable in space and time, since it strongly depends on soil texture and structure (Bagarello et al., 2004; Jirků et al., 2013; Schwen et al. 2011). Because $K_{s}$ is mainly determined at punctual scale on the field, a large number of measurements are necessary to assess the magnitude and structure of the variation of $K_{s}$ within an area of interest. To this aim, the SFH technique appears suitable to guarantee both measurements accuracy and high repeatability over time.

Examples of intensive sampling for $K_{s}$ determination at the plot scale were reported by Bagarello et al. (2010b; 2013a; 2020) and Baiamonte et al. (2017). In particular, with the aim of understanding and simulating hydrological processes (e.g., runoff), SFH was applied to a clay soil to explore the sample size effect on the summary statistics, and to determine the spatial variability at the plot scale (Bagarello et al., 2010b). To this end, two plots of $4 \times 11 \mathrm{~m}^{2}$ were intensively sampled by measuring $K_{s}-S F H$ on a total of 352 sampling points. The SFH technique was found to be able to measure a wide range of $K_{s}$ values (i.e., variations within three orders of magnitude), proving its capability to measure $K_{s}$ of both the soil matrix only and the soil with macropores and cracks. Conclusions have highlighted that the sampling strategy could vary with the aim of the research since: i) small sample size, i.e., $N \leq 19$, are enough to obtain representative means of $\rho_{b}$ and $\theta_{i}$, ii) higher sample size, i.e., $N \geq 84$, are necessary to obtain representative mean values of $K_{s}$, iii) sample size of 56-93 were adequate to obtain representative standard deviations and to study the spatial structure of the studied variables (Bagarello et al., 2010b). In the investigation by Baiamonte et al. (2017), the SFH technique was intensively applied (i.e., 120 points of measurements) to detect the spatial variability of $K_{s}$ at the catchment scale, and to assess the ability of soil physical characteristics, terrain attributes and land use classification, to plan sampling strategies for the estimation of $K_{s}$. Relatively high $K_{s}$ values were obtained for sites with both low clay content, high elevation, and mean slope. The differences in $K_{s}$ were detected also as a function of the land cover. Their findings showed that: i) soil texture had a main role on $K_{s}$ variability, ii) $K_{s}$ changed by more than four orders of magnitude, iii) SFH technique was usable to sample remote and quite inaccessible points of the catchment. However, Keller et al. (2012) have demonstrated how SFH technique may be able to detect significantly lower $K_{s}$ values in low-yielding zones than in high- and medium-yielding zones in a Swedish agricultural soil, as an effect of the well-known inverse relationship between $K_{s}$ and $\rho_{b}$ (i.e., $K_{s}$ decreases as $\rho_{b}$ increases). Since relatively lower values of $K_{s}$ can be associated with higher $\rho_{b}$ values (in other words, it was possible to identify nonoptimal proportions between air and water into the soil), $K_{s}$ proved to be a good predictor of crop yield, and SFH method may be suggested for research within the framework of precision agriculture.

Based on the investigations discussed so far, it appears quite evident that the SFH technique can be applied also for repeated measurements at the same place to evaluate the time evolution of $K_{s}$. Examples of temporal variability assessment of $K_{s}-S F H$ on orchards, using both temporary or permanent sampling points, were reported by Biddoccu et al. (2017) and Bagarello 
Table 1. SFH-application examples for saturated hydraulic conductivity $\left(K_{s}\right)$ characterization.

\begin{tabular}{|c|c|c|}
\hline Reference & Aim of SFH-application & Highlights of investigations \\
\hline $\begin{array}{l}\text { Azam et al. } \\
(2008)\end{array}$ & $\begin{array}{l}\text { Impact of cropping systems } \\
\text { (mungbean, cassava and maize) } \\
\text { on soil structural properties }\end{array}$ & $\begin{array}{l}\text { Residue management and tillage direction significantly affected only root density and } \\
\text { soil shrinkage, thus both enhancing and deteriorating soil structure; none of consid- } \\
\text { ered subsoil properties }\left(O M, \rho_{b} \text {, shrinking-swelling properties, rooted subsoil) were }\right. \\
\text { significantly influenced by any of the cropping systems studied. }\end{array}$ \\
\hline $\begin{array}{l}\text { Azam et al. } \\
(2009)\end{array}$ & $\begin{array}{l}\text { Assess and develop soil hydraulic } \\
\text { quality factors for optimum soil } \\
\text { water regime }\end{array}$ & $\begin{array}{l}\text { Principal component analysis and factor analysis identified eight factors affecting soil } \\
\text { hydraulic quality (SHQ): pore size distribution, shape and grade of water-stable } \\
\text { aggregates, shrinking-swelling, infiltration rate and sand fraction of Ap horizon. A } \\
\text { comprehensive SHQ index was developed for both topsoil and subsoil layers under } \\
\text { different cropping systems. }\end{array}$ \\
\hline Rex et al. (2013) & $\begin{array}{l}\text { Development a hydrologic hazard } \\
\text { assessment procedure in a pine } \\
\text { forest environment }\end{array}$ & $\begin{array}{l}\text { A set of hazard indicators was developed to decrease the likelihood of soil dis- } \\
\text { turbance from wood harvesting. Results showed that the most effective envi- } \\
\text { ronmental indicators were pine content and understory, soil texture and drain- } \\
\text { age density, and the topographic index. }\end{array}$ \\
\hline $\begin{array}{l}\text { Chyba et al. } \\
(2014 ; 2017)\end{array}$ & $\begin{array}{l}\text { Influence of soil compaction on } \\
\text { water infiltration rate }\end{array}$ & $\begin{array}{l}K_{s} \text { measurements showed an expected significantly higher infiltration rate in the non- } \\
\text { compacted than compacted soil; no differences were detected in soil compaction due } \\
\text { to cattle hooves or tractor. Results confirmed the negative effect of soil compaction } \\
\text { on soil water infiltration. The research allowed to highlight the positive effects of } \\
\text { controlled traffic farming. }\end{array}$ \\
\hline $\begin{array}{l}\text { Castellini et al. } \\
(2015)\end{array}$ & $\begin{array}{l}\text { Impact of biochar addition on a } \\
\text { clay soil }\end{array}$ & $\begin{array}{l}\text { Results showed no significant impact of biochar incorporation (5-10-20-30 g per } \\
\mathrm{kg}^{-1} \text { soil) on } K_{s} \text { values. }\end{array}$ \\
\hline $\begin{array}{l}\text { Leblanc et al. } \\
(2015)\end{array}$ & $\begin{array}{l}\text { Hydraulic characterization of } \\
\text { bauxite deposits }\end{array}$ & $\begin{array}{l}\text { The combined datasets (remote sensing, hydrochemistry, and hydrodynamics) al- } \\
\text { lowed to study the hydrology of Australians bauxite deposits. Investigation provided } \\
\text { a first conceptual hydrogeological model of the spring system functioning on the } \\
\text { hydrology of the bauxite oases. }\end{array}$ \\
\hline $\begin{array}{l}\text { Biddoccu et al. } \\
\text { (2016) }\end{array}$ & $\begin{array}{l}\text { Management effects on runoff } \\
\text { and soil erosion in sloping vine- } \\
\text { yards }\end{array}$ & $\begin{array}{l}\text { Highest runoff and soil losses were measured in autumn; grass cover was very effec- } \\
\text { tive in reducing soil losses in summer, but not in autumn; adoption of tillage for more } \\
\text { than } 8 \text { years caused increasing runoff and soil erosion. }\end{array}$ \\
\hline $\begin{array}{l}\text { Cherubin et al. } \\
(2016)\end{array}$ & $\begin{array}{l}\text { Soil physical quality (SPQ) re- } \\
\text { sponse to sugarcane expansion in } \\
\text { Brazil }\end{array}$ & $\begin{array}{l}\text { SPQ decreased from native vegetation }(\mathrm{NV}) \text {, to pasture }(\mathrm{P}) \text {, to sugarcane }(\mathrm{S}) \text {; soil } \\
\text { compaction limited soil aeration and water availability under } \mathrm{P} \text { and } \mathrm{S} \text {; soil tillage } \\
\text { under S had short-term positive effects over soil compaction; S soils were more prone } \\
\text { to degradation due to erosion processes }\end{array}$ \\
\hline $\begin{array}{l}\text { Servadio et al. } \\
\text { (2016) }\end{array}$ & $\begin{array}{l}\text { Adaptation of soil tillage to cli- } \\
\text { mate change under durum wheat }\end{array}$ & $\begin{array}{l}\text { A significant linear relationship between grain yield and soil penetration resistance } \\
\text { was detected; it suggested that soil strength may be good indicator for soil productivi- } \\
\text { ty. Reduced tillage, i.e., ploughing or harrowing soil to a } 20 \mathrm{~cm} \text { depth, were suitable } \\
\text { for investigate soil under climate change. }\end{array}$ \\
\hline $\begin{array}{l}\text { Šařec and Novak } \\
(2017)\end{array}$ & $\begin{array}{l}\text { Effects of manure and } O M \text { activa- } \\
\text { tors on soil physical properties }\end{array}$ & $\begin{array}{l}\text { High } K_{s} \text { values were always detected in all considered organic management, includ- } \\
\text { ing the control; results were linked to the light-textured soil of the trial plot. The } \\
\text { study was unable to demonstrate, in the short term, clear beneficial effects of manure } \\
\text { and activators on soil properties. }\end{array}$ \\
\hline $\begin{array}{l}\text { Kováŕ et al. } \\
\text { (2017) }\end{array}$ & $\begin{array}{l}\text { Comparison of tillage systems } \\
\text { effects on water infiltration }\end{array}$ & $\begin{array}{l}\text { Findings carried out for a loamy sand soil showed that tillage impacted water infiltra- } \\
\text { tion; the lowest } K_{s} \text { was obtained under oats by reduced tillage; conventional tillage } \\
\text { was most threatened by excessive run-off. This investigation confirmed the risk of } \\
\text { erosion on slope and light soil without the use of proper soil conservation techniques. }\end{array}$ \\
\hline $\begin{array}{l}\text { Erban et al. } \\
(2018)\end{array}$ & $\begin{array}{l}\text { Impact of herbicide glyphosate on } \\
\text { compost-amended soils }\end{array}$ & $\begin{array}{l}\text { The persistence of both glyphosate and its metabolite (AMPA) decreased with soil } \\
\text { depth; compost dose alone did not cause significant differences among samples; } \\
\text { differences on the behavior between glyphosate and AMPA were mainly related to } K_{s} \\
\text { and soil moisture. }\end{array}$ \\
\hline Preti et al. (2018) & $\begin{array}{l}\text { Modeling of water flow pathways } \\
\text { in agricultural } \\
\text { terraced landscapes }\end{array}$ & $\begin{array}{l}\text { The applied multidisciplinary experimental approach allowed to highlight that alt- } \\
\text { hough groundwater rise did not occur, as expected, infiltrated water accumulat- } \\
\text { ed behind dry-stone walls, causing an increase in pore water pressure; this } \\
\text { induced wall bulging and instability. Findings provided field evidences of water } \\
\text { circulation and led to the definition of hydrological functioning of farming ter- } \\
\text { raced systems. }\end{array}$ \\
\hline
\end{tabular}

and Sgroi (2007), respectively. In the first case, the temporal variability of soil management effects (i.e., soil compaction by machinery) on soil hydrological properties (i.e., runoff and erosion) was investigated at the field scale in a hillslope vineyard. In the second case, SFH was applied to investigate the intrinsic temporal variability of $K_{s}$ at permanent locations on the surface of a sandy loam soil over a two-year period. In both experimental fields, SFH appeared viable to study the $K_{s}$ variability both in space and time.

\section{BEERKAN ESTIMATION OF SOIL PEDOTRANSFER (BEST) PARAMETERS}

The BEST (Beerkan Estimation of Soil pedoTransfer parameters) procedure proposed by Lassabatere et al. (2006) assumes that the soil hydraulic properties follow the van Genuchten (1980) model with the Burdine (1953) condition for the water retention curve and the Brooks and Corey (1964) relationship for the hydraulic conductivity: 
Rapid and accurate measurement methods for determining soil hydraulic properties: A review

$$
\begin{aligned}
& \frac{\theta-\theta_{r}}{\theta_{s}-\theta_{r}}=\left[1+\left(\frac{h}{h_{g}}\right)^{n}\right]^{-m} \\
& m=1-\frac{2}{n} \\
& \frac{K(\theta)}{K_{s}}=\left(\frac{\boldsymbol{\theta}-\theta_{r}}{\theta_{s}-\theta_{r}}\right)^{\eta} \\
& \eta=\frac{2}{m n}+3
\end{aligned}
$$

where $\theta\left(\mathrm{L}^{3} \mathrm{~L}^{-3}\right)$ is the volumetric soil water content, $h(\mathrm{~L})$ is the soil water pressure head, $K\left(\mathrm{~L} \mathrm{~T}^{-1}\right)$ is the soil hydraulic conductivity, $n, m$ and $\eta$ are shape parameters, $h_{g}(\mathrm{~L})$ is a scale parameter for water pressure head, and $\theta_{r}\left(\mathrm{~L}^{3} \mathrm{~L}^{-3}\right)$ is the residual soil water content. BEST assumes that the residual water content is negligible, $\theta_{r} \approx 0$. To estimate the soil hydraulic parameters, BEST requires the cumulative infiltration curve obtained with the Beerkan test (Braud et al., 2005), the soil particle-size distribution (PSD), the bulk density, $\rho_{b}\left(\mathrm{M} \mathrm{L} \mathrm{L}^{-3}\right)$, and the initial water content, $\theta_{i}\left(\mathrm{~L}^{3} \mathrm{~L}^{-3}\right)$. In particular, BEST estimates the shape parameters $(m, n$ and $\eta)$ using the PSD and the soil porosity, $\phi\left(\mathrm{L}^{3} \mathrm{~L}^{-3}\right)$, while the cumulative infiltration is modeled to estimate the soil sorptivity, $S\left(\mathrm{~L} \mathrm{~T}^{-0.5}\right)$, and the scale parameters $h_{g}$ and $K_{s}$. The Beerkan test involves the determination of the 3-D cumulative infiltration resulting from the application of a slightly positive water pressure head over a disk source. Practically, a cylinder is inserted shallowly (e.g., $1 \mathrm{~cm}$ ) into the soil, a given small volume of water is poured in the cylinder at the start of the measurement and the elapsed time during the infiltration is measured. When the amount of water has completely infiltrated, an identical amount of water is poured into the cylinder, and the time needed for the water to infiltrate is logged. The procedure is repeated until the difference in infiltration times between consecutive trials become negligible, indicating a practically steady state infiltration (see video VT2, which link is enlisted in Table S1). In many BEST applications, $\phi$ is calculated from the $\rho_{b}$ data, assuming a soil particle density of $2.65 \mathrm{~g} \mathrm{~cm}^{-3}$, and $\theta_{s}$ is assumed to coincide with $\phi$ (Bagarello et al., 2014b). However, the determination of $\theta_{s}$ by other means is not expected to appreciably affect BEST predictions (Di Prima et al., 2017).

Three main BEST algorithms were developed: BEST-slope (Lassabatere et al., 2006), BEST-intercept (Yilmaz et al., 2010) and BEST-steady (Bagarello et al., 2014e). The three algorithms make use of the same input data, but differ by the way they fit the experimental data to the infiltration models for transient and steady states (Di Prima et al., 2018a). In particular, a fitting of the infiltration model to the transient data is required with BEST-slope and BEST-intercept, but these differ by the use of steady-state conditions described respectively by the slope, $i_{s}$ $\left(\mathrm{L} \mathrm{T}^{-1}\right)$, and the intercept, $b_{s}(\mathrm{~L})$, of the straight line fitted to the part of the experimental cumulative infiltration curve. Both of these last two terms are required by BEST-steady that does not need any data fitting to the transient stage of the run but relies solely on the steady state portion of the curve. More recently, Fernández-Gálvez et al. (2019) proposed a new BEST version based on the same approach but developed a new version that treats the whole dataset as a whole, regardless of the state (transient versus steady). Since a fitting of the infiltration model to the transient data is required with BEST-slope and BESTintercept, the accuracy of these fits is commonly assessed on the basis of the relative fitting error, $E_{r}$, as suggested by
Lassabatere et al. (2006):

$$
E_{r}=\sqrt{\frac{\sum_{i=1}^{k}\left[I_{\text {exp }}\left(t_{i}\right)-I_{\text {mod }}\left(t_{i}\right)\right]^{2}}{\sum_{i=1}^{k} I_{\text {exp }}\left(t_{i}\right)^{2}}}
$$

where $I_{\exp }$ and $I_{\text {mod }}$ stand for experimental and modelled cumulative infiltrations, respectively, and $k$ is the number of experimental data points selected to fit the transient state model. Note that the models use two infiltration constants $\gamma$ and $\beta$ that are usually equal to 0.75 and 0.6 , respectively. The values of these constants are usually admitted even some studies have already questioned their values (Lassabatere et al., 2009).

\subsection{BEST validation \\ 4.1.1 Soil hydraulic conductivity}

An extensive literature can be found on the validation of BEST-procedure for the estimation of the soil hydraulic conductivity (Angulo-Jaramillo et al., 2019, for a previous review). Available investigations have compared the saturated hydraulic conductivity estimations obtained with BEST and those independently obtained with standard methods, as the pressure infiltrometer (Reynolds and Elrick, 2002), Guelph permeameter (Reynolds and Elrick, 1985), bottomless bucket method (Nimmo et al., 2009), or the simplified falling head technique (Bagarello et al., 2004). On the other hand, a great attention was paid also in comparing BEST estimates of $K_{s}$ with those obtained applying other methods to analyze single-ring infiltrometer data.

In details, Bagarello et al. (2013b) compared $K_{s}$ data estimated by the BEST-slope algorithm from a total of 192 infiltration experiments carried out on Burundian and Sicilian soils with the estimates provided by the One Ponding Depth (OPD) approach (Reynolds and Elrick, 1990). These authors detected significantly higher $K_{s}-B E S T$ than $K_{s}-O P D$, however, the differences observed between $K_{s}$ estimates did not exceeded a factor of three in about $98 \%$ of the cases, with maximum discrepancies lower than a factor of 13.4 (Bagarello et al., 2013b). Alagna et al. (2016) applied BEST on a loam soil, using several applicative scenarios (i.e., $\theta_{s}=\phi$ or $\theta_{s}=0.76 \phi$ ), and compared $K_{s}$-BEST estimates with those obtained from the Two Ponding Depth (TPD) approach (Reynolds and Elrick, 1990). From a statistical point of view, the results showed comparable $K_{s}$ values for all the algorithms. However, the most satisfactory match between $K_{s}$ estimations was obtained when BEST-intercept (with $\theta_{s}=0.76 \phi$ ) was used. In this case, differences in $K_{s}$ estimates never exceeded $1.9 \%$ on average (Alagna et al., 2016). These authors also compared BEST with four other methods, including tension infiltrometers, the bottomless bucket (BB) or simplified falling head (SFH) methods. Since this comparison of BEST with BB or SFH revealed no great differences (on average, differences by a factor 1.2 or 1.5 , respectively), the authors concluded that BEST, TPD, BB and SFH methods yielded statistically similar estimates of $K_{s}$ for the sampled area (Alagna et al., 2016).

$\mathrm{Xu}$ et al. (2012) applied the $\mathrm{Wu} 1$ and $\mathrm{Wu} 2$ methods designed by Wu et al. (1999) to calculate $K_{s}$ for each Beerkan infiltration run and to establish a comparison between BEST algorithms for different textured soils (coarse, intermediate or fine soils). Their results showed that the four methods applied, i.e., BEST-slope, BEST-intercept, Wu1 and $\mathrm{Wu} 2$, were well correlated to each other in estimating $K_{s}$; however BESTintercept and $\mathrm{Wu} 2$ resulted in relatively higher $K_{s}$ values, while 
BEST-slope better matched with Wu1. On the other hand, as $\mathrm{Wu} 2$ method is based on a generalized solution for single ring that works similarly to the one adopted by BEST, i.e., when ponded depth of water on the soil surface is very small (i.e., close to zero), comparison between BEST and Wu2 may be considered reasonably reliable. Therefore, for a given soil, i.e., sandy, loamy or clayey, reported differences between $\mathrm{Wu} 2$ and BEST-slope were equal at most to a factor, $1.8,3.6$ or 5.9 respectively, while these differences were equal to a factor 0.7 , 0.7 or 1.3 in the comparison Wu2-BEST-intercept (Xu et al., 2012). Smaller differences, but still significant, were observed by Aiello et al. (2014) for another sandy loam soil (ratio Wu2BEST-slope around 1.1) when the infiltration constants $\beta$ and $\gamma$ were fixed to values of 1.9 and 0.79 , respectively. The authors concluded that although statistically significant, the differences were negligible from a practical point of view (Aiello et al., 2014). A summary of the comparisons between BEST methods and other methods is depicted in Figure $3 b$.

In summary, cited works show a satisfactory ability of BEST methods to yield reliable estimations of $K_{s}$ and with values comparable to other standard and more cumbersome methods, under several experimental conditions or for a wide range of soil textures and experimental conditions. Consequently, it can be an adequate choice, for example, for intensive soil sampling (studies on space-time variability), or for carrying out repeated measurements in places relatively inaccessible to reach. However, analogous signals of accuracy were reported when BEST was tested under not completely homogeneous conditions. Mubarak et al. (2010) assessed the temporal stability of both $K_{s}$ and spatial structure of hydraulic properties of a loamy soil. Under relatively similar pedologic and agronomic conditions, they compared $K_{s}$-BEST data with those estimated seventeen years earlier using the Guelph permeameter. Results showed that $K_{s}$ changed significantly, but observed discrepancies were not higher than a factor three or four, suggesting that BEST can constitute an easy, robust, and inexpensive way for characterizing soil hydraulic behavior and its spatial and temporal variability at the field scale (Mubarak et al., 2010).

\subsubsection{Soil water retention curve}

The reliability of the soil water retention estimation obtained by BEST was studied by establishing comparisons with standard laboratory methods. If compared to soil hydraulic conductivity validation, however, relatively little attention has been paid for water retention validation since a lower number of researches are available on this topic. In the few works specifically conducted at this aim, direct measurements of the soil water retention curve were obtained by the evaporation method or by a combination of other standard laboratory methods (sand-box or Buchner funnel and the Richards's pressure cells).

In details, for a sandy loam soil, Aiello et al. (2014) showed a relatively satisfactory match between estimated and measured soil water retention data when BEST-slope was used and when the infiltration constants, $\beta$ and $\gamma$, were optimized at a value of 1.9 and 0.79 , respectively. However, a general underestimation of the water retention curve by BEST was highlighted in their investigation (Aiello et al., 2014). A satisfactory accuracy in predicting the soil water retention of a loamy soil was reported by Alagna et al. (2016) using BEST-slope when a value of $\theta_{s}$ lower than the soil porosity $\left(\theta_{s}=0.76 \phi\right)$ was used. Similarly, Bagarello et al. (2014d) showed that the soil water retention was satisfactorily estimated by BEST, only when a value of $\theta_{s}$ lower than soil porosity was considered $\left(\theta_{s}=0.93 \phi\right)$. This suggests that a specific calibration can significantly improve the reliability of the prediction of the soil water retention curve. However, similar findings were obtained in other works (Castellini et al., 2018) when a simplified approach of BEST was applied, i.e., with the use of the general condition $\theta_{s}=\phi$ and the values of the infiltration constants as suggested in the literature $(\beta=0.6$ and $\gamma=0.75)$. In this regard, the applicability of the BEST to estimate the water retention curve was evaluated by Castellini et al. (2018) using a standard experimental approach, namely without performing an ad-hoc calibration for $\beta$ and $\gamma$ constants. The impact of $\beta$ and $\gamma$ on the estimates of $h_{g}$ was carried out for four real soils (i.e., a sandy, a silty-loam and two sandy-loam soils) and considering the three existing BESTalgorithms. Moreover, the reliability of the soil water retention estimations was checked establishing a comparison with laboratory measures of the water retention curve using the evaporation method. The results of the sensitivity analysis showed that when BEST-slope was applied, $h_{g}$ values tended to decrease at increasing $\beta$ and $\gamma$ values; this results in more variable values than for the other two algorithms and a higher sensitivity to $\beta$ than $\gamma$. Also, since a lower variability of the estimated $h_{g}$ values was detected with BEST-intercept and BEST-steady due to the independence of $h_{g}$ from $\gamma$, relatively different mean $h_{g}$ values are expected, as a consequence of the different success rate among BEST-algorithms (Castellini et al., 2018). The authors concluded that although $h_{g}$ estimates depend on the selected algorithm (i.e., slope or intercept/steady), the sample size and their success rate (i.e., the percentage of obtaining non-negative values of $K_{s}$ and $S$ ), the expected discrepancies in $h_{g}$ estimation may be considered negligible for practical applications. Regarding the ability to accurately reproduce the soil water retention curve, main results by Castellini et al. (2018) showed that: i) BEST tended to underestimate soil water retention for three of the four considered soils; ii) regardless of the considered soil, BEST-slope generally provided the lowest root mean squared difference values; iii) specific calibration of the $\beta$ and $\gamma$ constants allowed to improve the accuracy and the goodness of fits. They concluded that the BEST-slope algorithm was the best choice to accurately estimate the water retention of the soil. A further comparison between $\theta$ values predicted by BEST-steady and the corresponding measurements obtained in lab (Buchner funnel + Richards's pressure cells) was provided by Castellini et al. (2020a), for a sandy loam no-tilled soil and a sandy-clayloam tilled soil. Overall, BEST's ability to estimate the soil water retention was comparable between the two soils because the root-mean-square deviations were equal to 0.068 and 0.072 $\mathrm{cm}^{3} \mathrm{~cm}^{-3}$, respectively. This suggested that, regardless of the soil texture or the soil management (no-tillage or minimum tillage), the accuracy degree of the $\theta$ estimations was comparable. However, some discrepancies were detected as a function of the applied soil pressure head, because BEST seems to have returned more accurate estimations near to water saturation or under unsaturated soil conditions depending on the site considered (Castellini et al., 2020a). Finally, Siltecho et al. (2015) determined the unsaturated soil hydraulic properties of different soils and compared their hydraulic functions with different methods (BEST, tension infiltrometer, evaporation method, PTFs). Although the authors did not provide any statistical results to summarize the comparison BEST vs. evaporation method, Figure 3 of their paper shows that BEST-slope overestimated the water retention for pressure head values close to water saturation while underestimating the water retention under unsaturated conditions. However, because none of these methods could clearly be considered superior to the others in terms of providing better parameters for modeling soil water 
flow, they concluded that the cheapest and easiest method to derive the van Genuchten parameters, like BEST method, may be used to achieve this goal (Siltecho et al., 2015).

Literature reported a non-negligible impact of $\beta$ and $\gamma$ estimation on soil water retention curve accuracy. However, simplifications may be suggested to improve, in the future, the correspondence between observed and estimated water retention curves (Latorre et al., 2018). Considering a 1D infiltration process, in fact, $\gamma$ could be omitted while $\beta$ has a negligible effect on the infiltration curve (Latorre et al., 2018). However, suggested approximations need to be verified experimentally with ad-hoc investigations.

\subsection{BEST application}

Several applicative examples of the BEST-procedure are available in the literature. However, the thirty-four studies selected in this review can be grouped according to the main goal of each investigation, and four main topics were identified: i) BESTapplication for soil hydraulic characterization, ii) soil sealing and crust assessment, iii) soil use impact on physical and hydraulic properties, iv) soil physical quality assessment. Therefore, except for the first group that was summarized in Table 2, remaining topics were discussed selecting only representative works, as summarized in the subsequent subsections.

Table 2. BEST-application examples for soil hydraulic characterization.

\begin{tabular}{|c|c|}
\hline Reference & Aim of BEST-application \\
\hline $\begin{array}{l}\text { Mubarak et al. } \\
\text { (2009a; } \\
\text { 2009b) }\end{array}$ & $\begin{array}{l}\text { Temporal variability in soil hydrau- } \\
\text { lic properties under drip irrigation }\end{array}$ \\
\hline $\begin{array}{l}\text { Mubarak et al. } \\
\text { (2010) }\end{array}$ & $\begin{array}{l}\text { Spatial analysis of soil surface } \\
\text { hydraulic properties }\end{array}$ \\
\hline $\begin{array}{l}\text { Cannavo et al. } \\
(2010)\end{array}$ & $\begin{array}{l}\text { Characterization and spatial distri- } \\
\text { bution of sediment layer deposited } \\
\text { in the stormwater infiltration basin }\end{array}$ \\
\hline $\begin{array}{l}\text { Lassabatere et } \\
\text { al. }(2010)\end{array}$ & $\begin{array}{l}\text { Effect of sediment accumulation on } \\
\text { the water infiltration capacity of } \\
\text { two urban infiltration basins }\end{array}$ \\
\hline $\begin{array}{l}\text { Bagarello et } \\
\text { al. (2011) }\end{array}$ & $\begin{array}{l}\text { Hydraulic characterization and soil } \\
\text { physical quality estimation of } \\
\text { Burundian soils }\end{array}$ \\
\hline
\end{tabular}

Highlights of investigations

Soil porosity and hydraulic properties changed over time; they should be taken into account when simulating soil water transfer under drip irrigation, to improve irrigation scheduling.

Spatial correlations of soil hydraulic properties were temporally stabilized in the 17year period, due to soil texture and structural properties which were constantly renewed by the cyclic agricultural practices.

Soil parameters linked to clogging phenomenon in the infiltration basin and the effect of sediment content variability on some physical transfer properties were defined. A significant influence of $O M$ and clay content on soil pore distribution and a negative correlation with $K_{s}$ was detected, but uncertainties about the role of both clay mineralogy and $O M$ on the studied processes were declared.

Lassabatere et Effect of sediment accumulation on Sediments reduced local water infiltration capacities due to their lower $K_{s}$; numerical results demonstrated that the settlement of a sedimentary layer may trigger a decrease in water infiltration and thus affect the hydraulic performance of basins.

Limiting the texture information to only the clay, silt and sand contents, instead of considering the full PSD, did not worsen the soil hydraulic characterization obtained by BEST. The used simplified approach has practical importance, especially in areas where soil hydraulic characterization is difficult due to the lack of laboratories and skilled personnel.

\begin{tabular}{lll}
\hline Bien et al. & $\begin{array}{l}\text { Assess the transfer of heterogene- } \\
\text { ous flows of water and solute in a }\end{array}$ & $\begin{array}{l}\text { BEST allowed to estimate the hydrodynamic properties of the sand and of a bimodal } \\
\text { material. This investigation provided relevant information on the coupling between }\end{array}$
\end{tabular}
heterogeneous and unsaturated hydrodynamic processes and pollutant transfer in unsaturated heterogeneous soils. medium

Goutaland et Sedimentary and hydraulic characal. (2013) terization of a heterogeneous glaciofluvial deposit and modeling of unsaturated flow

BEST allowed to characterize finely textured materials; numerical modeling highlighted the existence of preferential flow paths, associated with the sedimentary heterogeneity. The study increased the knowledge on modeling water flow and funneled flow in the vadose zone and their impact on pollutants transfer.

Gette- Impact of sediment deposition and Bouvarot et al. biofilm growth on the hydraulic (2014) properties and on hydrological processes (groundwater recharge)

A reduced permeability due to clogging of the top sedimentary layer in two infiltration basins was detected; highest reduction of permeability occurred in the basin colonized by the largest algal biomass. The detected link between hydraulic and microbial characteristics suggested that algal biofilm growth impacted on the hydraulic performance of the infiltration basins.

Coutinho et al. Hydraulic characterization and (2016) hydrological behaviour of a pilot permeable pavement in an urban centre

BEST allowed to characterize a permeable pavement (PP) and simulations performed on HYDRUS showed the good potential of the PP for rainfall-runoff management; PP was evaluated suitable to restore existing urban parking infrastructure and to promote hydrological behaviour close to natural soils.

Khaledian et Impact of soil tillage on spatio- $\quad$ Hydraulic properties $\left(K_{s}, S\right.$ and bulk density) changed over time, due to i) wetting and al. (2016) temporal variation of soil properties drying cycles, ii) soil biological activity and iii) the effects of the root system. To under drip irrigation

Braud et al. Mapping topsoil $K_{s}$ measurements (2017) using different methods mitigate agro-environmental risk, the application of fertilizers should be done after the restructuration of tilled soil.

The authors proposed a simple method, based on the analysis of distributions and regressions, to pool together values of $K_{s}$ obtained on the topsoil and using different infiltration methods; different methods may lead to differences of several orders of magnitude in the estimated $K_{s}$; because geology and land cover were found to be discriminating factors on $K_{s}$, they were used to propose a method for mapping topsoil $K_{s}$ in the investigated region.

Kanso et al. Spatial variability of soil hydraulic $\quad$ Results showed high spatial variability in $K_{s}$, which was dominant relative to uncertain(2018) properties in sustainable urban ties in PTFs predictions and those induced by experimental errors; simulations revealed that peak flows and volumes are highly affected by the spatial variability of soil hydraulic properties. This study provided insight regarding the spatial variability of soil hydraulic properties and its implications for hydrological performance of roadside SuDS. 


\subsubsection{Soil physical and hydraulic characterization by BEST}

Fourteen investigations were summarized in Table 2 to account for agro-environmental applications mainly addressed to characterize the hydraulic properties of several types of porous media (i.e., agricultural soils, sediments), to establish their spatio-temporal variability, or to support the modeling of the dynamics of hydrological processes at hillslope and catchment scales. Therefore, aims and highlights of these investigations were reported.

\subsubsection{Soil sealing and crust assessment}

Droplet impact during rainfall events can modify the soil structure at surface, since the dissipation of kinetic energy of water on the soil can cause the destruction and dispersion of soil aggregates, leading to the formation of a thin sealed layer at surface with a higher density and a lower permeability. As a consequence, runoff may increase and enhance soil erosion (Assouline and Mualem, 2002). Common methodological approach to determine and study the effects of rainfall on the hydrodynamic soil properties make use of rainfall simulators (Armenise et al., 2018). Rainfall experiments are an attractive approach as they combine several advantages, including precision, accuracy and reproducibility, offering a systematic approach to address the different factors that influence the studied processes (Di Prima et al., 2017; Iserloh et al., 2013). However, the effects of soil sealing on the soil properties were recently studied also applying the BEST-procedure.

In details, Bagarello et al. (2014b) evaluated the effect of the height of water pouring on soil hydraulic properties when using the SFH and BEST methods. The most appropriate BEST algorithm to analyze the data was identified and the effect of the height of water pouring (low and high, respectively at 3 and $150 \mathrm{~cm}$ ) on the soil hydraulic properties was assessed for four Sicilian soils. The main results showed that: i) the soil surface disturbance induced by water pouring from different heights negatively affected the estimation with BEST-slope but not with BEST-intercept, only the latter being usable for low steady-state infiltration rates; ii) the height of water application influenced significantly only $K_{s}-B E S T$, with the low runs yielding higher means (by a factor of 11-35) than the high runs. Therefore, BEST with a high run was suggested to mimic the rainfall impact of water droplets on soil surface, thus allowing the study of surface runoff generation phenomena during intense rainfall events (Bagarello et al., 2014b). In a similar investigation, two-stage infiltration runs differing by the height of water pouring in the second stage of the run (i.e., low or high, respectively at 3 and $150 \mathrm{~cm}$ ) were used by Bagarello et al. (2017c) to better understand the effects of antecedent soil water content or bulk density on infiltration runs. The results showed that: i) the duration of the second stage, for the same amount of infiltrated water, of the infiltration process was 2.2 times higher than the corresponding values of the first stage, but it increased by a factor 4.5 when a high of water pouring of $150 \mathrm{~cm}$ was used; ii) the height of water pouring influenced the infiltration process when the soil was initially very wet; iii) a less compact soil was found to be more sensitive to the height of water pouring as consequence of the effect of water height on macroporosity. The authors concluded that this low-high infiltration run methodology carried out with BEST seems usable to detect the effects of the simulated rainfall on infiltration parameters. Di Prima et al. (2018a) compared BEST to the most common rainfall simulator method to establish the surface sealing effect on both infiltration process and $K_{s}$. These authors prepared different textured bared soils to expose them to the direct impact of raindrops from low $(L=3 \mathrm{~cm})$ or high $(H=25 \mathrm{~cm})$ runs. In addition, rainfall experiments were carried out on layered systems made of the same soils and with different depths. The results showed that the soil sealing resulted in an increase in soil bulk density and drastically impacted the infiltration processes. The treatment of the data with BEST methods proved that the $K_{s}$ estimates were more representative of the seal than the layer below, as suggested by Lassabatere et al. (2010).

As compared to the $K_{s}$ estimates obtained from the rainfall experiments, BEST-steady applied to BEST-H run (with $H$ that is the water pouring height of $25 \mathrm{~cm}$ ) was identified as the best combination to properly measure the seal's saturated hydraulic conductivity. This methodology proved very efficient for the study of an initially undisturbed soil directly impacted by water with minimal experimental efforts, small volumes of water and easily transportable equipment (Di Prima et al., 2018a). Examples of $K_{s}$ estimation on crusted soils were reported by Touma et al. (2011), Alagna et al. $(2013 ; 2019)$ and Souza et al. (2014). With reference to these last works, Souza et al. (2014) have provided a representative example of BEST-application, for a castor bean crop with visible formations of soil crusts. More specifically, they applied a simplified procedure for estimating soil indicators such as the macroscopic capillary length, the dimension and number of conductive pores. This characterization procedure allowed to demonstrate that the investigated soils were three times more conductive and almost three times more productive when no affected by crusting phenomena. In conclusion, experimental procedures based on BEST may be suggested as a valid alternative to the more traditional and cumbersome methods like rainfall simulators for the identification of the factors affecting runoff and soil erosion.

\subsubsection{Soil use impact on physical and hydraulic properties}

Cropping systems and agronomic practices (i.e., crops rotation, soil tillage) may deeply modify the physical and hydraulic properties of the soil. Therefore, since soil use impact evaluation may require extensive and cumbersome experimental efforts, the availability of easy and accurate methods represent the prerequisite to support environmental sustainability assessments of some agronomic practices.

Several studies applied BEST to investigate specifically the impact of land use on soil physical and hydraulic properties. For example, in an agronomic study carried out in France, Khaledian et al. (2012) used BEST to study whether the tillage improves soil hydraulic parameters as compared with conventional tillage or not. Castellini et al. (2019a; 2020b) applied BEST to investigate different soil tillage options (notillage, minimum tillage) in southern Italy; starting from soil functions obtained by BEST, they estimated some soil physical indicators (among others, number and size of hydraulically active pores, air capacity, plant available water capacity, macroporosity) to assess the impact of soil tillage on soil pores network. Also, in the south China, it has been applied to study the effects of Napier grass management on soil hydrologic functions in a karst landscape and to identify reasonable strategies for maintaining soil hydrologic function (Yang et al., 2016), or to establish the impact of different vegetation restoration types on $K_{s}$, within a largest global ecological restoration engineering project (Yang et al., 2017). Similarly, the effects of native, spontaneous or exotic vegetation on soil hydraulic properties were evaluated in areas of France (Gonzalez-Merchan et al., 2014), Mexico (Reyes-Gómez et al., 2015) and Brasil (Celentano et al., 2017; Lozano-Baez et al., 
2018). Therefore, cited references suggest that BEST is a suitable method for spatially distributed investigations, carried out under very varied operating conditions. Investigation at catchment scale by Gonzalez-Sosa et al. (2010), confirms this statement. Finally, Grimaldi et al. (2014) used BEST to assess the relative contributions of successive land-use changes and spatial variations in the physical environment on ecosystem services at the plot and farm scales. Examples of possible applications of BEST in the field are shown in Figure 5.

\subsubsection{Soil physical quality assessment}

In the last thirty years the concept of soil quality has received great attention from the scientific community. Specifically, soil physical quality (SPQ) indicators are significant since they are linked to the soil's ability to store and transmit water and air. Usually, capacity-based indicators of SPQ (among others, air capacity, relative field capacity) are obtained from water retention curve experimentally determined in the laboratory (Castellini et al, 2013). On the other hand, the SPQ may be estimated using soil indicators calculated at the inflection point of the soil water retention curve, as suggested by Dexter (2004). Consequently, the possibility of obtaining SPQ estimations in a simple, inexpensive and relatively accurate way is attractive for many agro-environmental purposes (Castellini et al., 2019b; Souza et al., 2017).

Some investigations were aimed at evaluating BEST ability to assess the SPQ for agricultural and forest environments. For instance, Di Prima et al. (2018b) assessed SPQ of a Spanish orchard under three different soil managements, i.e., no-tillage using herbicides, conventional tillage under chemical farming, no-tillage under organic farming, and common indicators such as $\rho_{b}$, organic carbon content, or structural stability index were considered in conjunction with capacitive indicators estimated by BEST. The results showed that independent and BESTderived indicators yielded similar information, suggesting their ability to distinguish SPQ among contrasting soil managements. In addition, their findings also showed that organic farming positively impacted the SPQ, suggesting that too frequent soil tillage and herbicide treatments should be avoided. Cullotta et al. (2016) compared different experimental methodologies and SPQ assessment criteria in a Sicilian forest and pasture environment. Specifically, the suitability of the BEST procedure to reproduce a SPQ assessment based on laboratory measurements was tested. With lab data of soil water retention, only the criterion using capacity-based indicators (e.g., air capacity, macroporosity) has suggested that the SPQ increased as external pressures decreased; conversely, BEST was more prone to detect good soil quality conditions, and was less able to discriminate between experimental plots. Consequently, i) developing BEST for SPQ assessment is advisable since parameters descriptive of both the water retention and hydraulic conductivity functions can be collected with a single experiment and a relatively low effort (Castellini et al., 2016), ii) establishing further comparisons between measured and estimated SPQ indicators, respectively from lab or BEST experiments, using appropriate data sets, is necessary to establish the reliability of the use of BEST estimates for such goals.

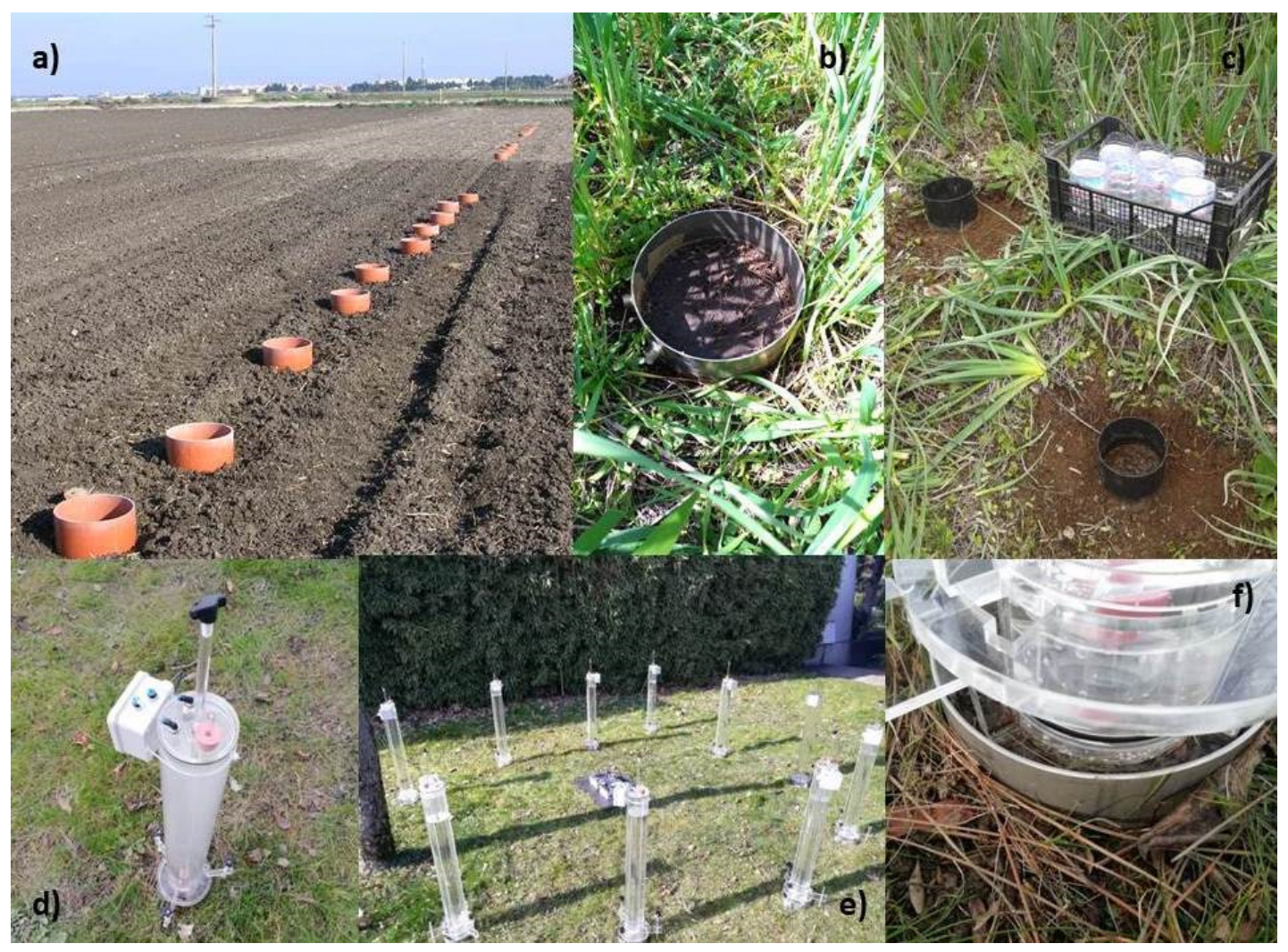

Fig. 5. Application of SFH (a) and BEST-Beerkan (b-e) methods in the field under different agro-environmental conditions, i.e., bare soil $(a, d, e)$, winter wheat crop (b), Mediterranean maquis (c), and details of the automatic infiltrometer (f). 


\subsubsection{BEST use for urban soil applications}

In addition to agricultural applications, BEST methods were also used for the characterization of urban soils. Lassabatere et al. (2010) used the BEST method to study the clogging of the soil surface in infiltration basins. These basins infiltrate stormwater previously collected over urban and peri-urban catchments (Fletcher et al., 2015). Stormwater carries large amounts of suspended solids that deposit at the soil surface of the infiltration basin. A sedimentary layer forms, clogs the basin, and impedes water infiltration into the subsoil. Lassabatere et al. (2010) used BEST methods to characterize the hydraulic functions of the subsoils and the sedimentary layers, and implemented the estimated hydraulic parameters in Hydrus model (Šimŭnek et al., 2016) to simulate the effect of the sedimentary layer on water infiltration for several typical rainfall events and meteorological chronics. They clearly proved the drastic effect of clogging for the two studied infiltration basins. By doing so, the authors pointed at the potential of BEST methods for quantifying the effect of clogging on the operation of infiltration systems.

With the aim of understanding unsaturated flow in infiltration basins, Goutaland et al. (2013) used the BEST methods to characterize the lithofacies (materials) constituting the glaciofluvial deposit lying under the soil surface. The same authors used these properties to model water drainage in a transect of soil (13 m long and $2.5 \mathrm{~m}$ deep) from a saturated initial state. Further studies used the same hydraulic parameters and soil transect to model unsaturated flow for several initial states and flowrates imposed at the soil surface (Ben Slimene et al., 2017). These two studies proved that the contrast in hydraulic properties triggered the development of funneled flows between the sandy and gravel inclusions, due to capillary barrier effect, in particular under unsaturated conditions, i.e., for dry initial conditions and low water fluxes imposed at surface. The knowledge of the degree of preferential flow is of paramount importance for the prediction of the fate of pollutant, since preferential flow restrict the access of pollutants to the soil reactive matrix (Lassabatere et al., 2004; 2007). Other similar applications of BEST methods for the characterization of other works developed for the management of stormwater (e.g., rain garden, permeable pavements, etc.) can be found for instance in Coutinho et al. (2016) or Bouarafa et al. (2019).

The last original example of application of BEST methods was proposed by Yilmaz et al. (2010; 2013). These authors investigated the effect of weathering processes on the Basic Oxygen Furnace (BOF) slags and their hydraulic properties. These byproducts of steel industry were considered as good candidate for alternative materials for road construction. However, this type of material reacts in contact with the atmosphere, portlandite $\mathrm{Ca}(\mathrm{OH})_{2}(\mathrm{~s})$ being transformed into calcite Ca$\mathrm{CO}_{3}(\mathrm{~s})$. Yilmaz et al. (2013) proved that such chemical reactivity tends to impact the porosity with the clogging of some pores, thus impacting the material's hydraulic parameters. Yilmaz et al. (2010) were able to quantify such an effect on the saturated and unsaturated hydraulic properties, with a clear decrease in the saturated hydraulic conductivity. These examples show also the advantage and interest of using BEST methods for managing urban soils.

\section{SIMPLIFIED METHODS BASED ON A BEERKAN INFILTRATION RUN: TSBI AND SSBI}

Two simplified methods were developed to estimate $K_{s}$ from Beerkan data. Bagarello et al. (2014a) and Bagarello et al. (2017a) proposed two versions of a simplified method based on a Beerkan infiltration run (SBI methods), differing by the use of transient or steady states infiltration data. The acronyms TSBI (Transient SBI) and SSBI (Steady SBI) were suggested to denote these methods, whose advantage is that they do not require additional field and laboratory measurements to estimate $K_{s}$, such as initial and final soil water content, particle size distribution or bulk density.

With the TSBI method, the slope, $b_{1}\left(\mathrm{~L} \mathrm{~T}^{-1}\right)$, of the linearized cumulative infiltration curve, estimated by a linear regression analysis of the $I / \sqrt{ } t$ vs. $\sqrt{ }_{t}$ plot, is used to estimate $K_{s}$ by the following relationship (Bagarello et al., 2014a):

$$
K_{s}=\frac{b_{1}}{0.467\left(\frac{2.92}{r \alpha^{*}}+1\right)}
$$

where $r(\mathrm{~L})$ is the radius of the ring and $\alpha^{*}\left(\mathrm{~L}^{-1}\right)$ is a parameter expressing the relative importance of gravity and capillary forces during an infiltration process (Reynolds and Elrick, 1990). A soil dependent $\alpha^{*}$ value may be selected from the table proposed by Elrick and Reynolds (1992) (summarized in Figure 2). Bagarello et al. (2013b; 2014a) compared $K_{s}-T S B I$ data with those determined by BEST and the OPD approach. According to these authors, TSBI approach provides approximate estimations of $K_{s}$ close to OPD methods. Specifically, BEST-slope yielded significantly higher $K_{s}$ data than TSBI (factor of 1.3), when both methods were applied to a relatively large data set $(N=192)$; a statistically significant correlation was detected between $K_{s}-B E S T$ and $K_{s}-T S B I\left(R^{2}=0.78\right)$, but the regression line differed significantly from the identity line (Bagarello et al., 2013b). On the other hand, a total of 149 Beerkan runs, representing a wide range of $K_{s}$ values, were used to compare TSBI and BEST-slope (Bagarello et al., 2014a). The results showed that, when a value of first approximation of $\alpha^{*}$ was used $\left(0.012 \mathrm{~mm}^{-1}\right), K_{s}-B E S T$ and $K_{s}-T S B I$ showed i) significant differences, ii) a significantly correlation and iii) a regression line that differed from the identity line (Bagarello et al., 2014a). However, observed differences between $K_{s}$ values were within a factor of 2 for about $99 \%$ of the studied cases (maximum error by a factor 2.06).

The SSBI method makes use of the slope, $i_{s}\left(\mathrm{~L} \mathrm{~T}^{-1}\right)$, of the straight line defined by the last part of the cumulative infiltration describing the steady-state conditions. With this method, $K_{s}$ is estimated as follows (Bagarello et al., 2017a):

$$
K_{s}=\frac{i_{s}}{\frac{1.3635}{r \alpha^{*}}+1}
$$

The advantage of this latter method is that it considers only the steady phase of the infiltration process, thus avoiding the uncertainties due to a specific shape of the cumulative infiltration, owing to soil sealing or water repellency (Di Prima et al., 2019). For instance, Lozano-Baez et al. (2018; 2019) applied the SSBI method to investigate the effect of forest restoration on $K_{s}$ and its recovery to the pre-disturbance soil conditions. These authors used the SSBI method to overcome the failure of the BEST-steady algorithm to provide positive $K_{s}$ values under hydrophobic conditions encountered mainly at the forested sampled sites. In particular, $K_{s}$ data were measured under three land-cover types, i.e., pasture, restored forest and a remnant forest patch. They found considerable differences in soil hydraulic properties between land-cover classes. The highest $K_{s}$ values were observed in remnant forest sites and the lowest $K_{s}$ 
were associated with pasture sites. Their results suggested that soil properties and $K_{s}$ recovery are affected by prior land use, and this should be considered for forest management.

An improvement of the SSBI method for a reliable $K_{s}$ estimation was proposed by Di Prima et al. (2020a). These authors suggested estimating $\alpha^{*}$ by only using the steady-state data of a Beerkan infiltration experiment (to determine the intercept $b_{s}$ ) and a measurement of the saturated and initial volumetric soil water contents:

$$
\begin{aligned}
\alpha^{*} & =\frac{\Delta \theta}{b} \frac{C}{b_{s}} \\
C & =\frac{1}{2(1-\beta)} \ln \left(\frac{1}{\beta}\right)
\end{aligned}
$$

where $\Delta \theta=\theta_{s}-\theta_{i}$, and $\beta$ and $b$ are dimensionless infiltration constants, often fixed at $\beta=0.6$ and $b=0.55$, as commonly suggested by many investigations (Haverkamp et al., 1994; White and Sully, 1987). Note that the reciprocal of the $\alpha^{*}$ is the macroscopic capillary length, $\lambda_{c}(\mathrm{~L})$ (Angulo-Jaramillo et al., 2016). Di Prima et al. (2020a) demonstrated that, under some common assumptions and for a given $\Delta \theta$ value, $b_{s}$ is a reliable predictor of $\alpha^{*}$. Indeed $b_{s}$ is sensitive to the relative importance of capillary and gravity forces during ponded infiltration because its magnitude depends on the entire infiltration curve, including the transient phase (Angulo-Jaramillo et al., 2019). Specifically, small $b_{s}$ values indicate a linear infiltration curve, i.e., when gravity prevails over capillarity, which occurs primarily in coarse-textured and/or highly structured porous media. On the contrary, high intercept values indicate conditions when capillarity prevails over gravity, particularly in the transient infiltration phase, which occurs primarily in fine-textured soils. This approach can also help users to better estimate $K_{s}$ from field infiltration measurements and avoid uncertainty due to an imprecise description of the transient state of infiltration, and any subjectivity caused by the selection of a representative $\alpha^{*}$ value based solely on textural or structural characteristics.

\section{SHARED FREE TOOLS FOR A SIMPLER APPLICATION OF THE METHODS}

Video tutorials (VTs) are tools that can help to spread experimental procedures. Practical examples of how to perform correctly infiltration experiments of SFH or Beerkan type, in fact, can facilitate the diffusion and improve the quality of the obtained measurements. However, preliminary operations, i.e., a proper soil cleaning and a correct ring insertion into the soil, may represent the prerequisite to obtain high quality measurements. Links to nine VTs were reported Table S1. VTs number one to three show the application of SFH and Beerkan (VT3, a simplified method based on Beerkan infiltration run).

A new single-ring infiltrometer realized using low-cost components and open source technologies was presented by Di Prima (2015) to automate data collection under constant head conditions. This prototype was tested and successfully validated by Di Prima et al. (2016) and improved by Concialdi et al. (2020), who also quantified the accuracy of $K_{s}$ and $S$ for the different existing BEST methods and for a large panel of soil texture, using synthetic numerically generated data (Figure $5 \mathrm{e}-\mathrm{f})$. The validation showed that the automatic data collection increased measurement speed, allowed a more efficient data handling and analysis, and reduced the sensitivity of the calculated hydraulic parameters using BEST method. However, in addition to the theoretical information provided in the aforementioned papers, VT4 shows clearly the operation of the infiltration and how the infiltration process evolves over time. In addition, Di Prima et al. (2020b) used the devise in conjunction with time-lapse ground-penetrating radar (GPR) surveys to create three-dimensional (3D) representations of infiltrated water (see Figure 3 in Di Prima et al., 2020b). The use of the automatic infiltrometers in this protocol simplified the field setup, while also reducing the amount of effort needed to characterize water infiltration. Therefore, it could be of interest to better understand how the method works. Detailed schemes to assemble the automatic infiltrometer (components and code for data acquisition) can be found on the website bestsoilhydro.net. We encourage the readers to check the website bestsoilhydro.net for the latest updates, and also to download: Arduino sketches, electronic schemes, codes for data treatment, lists of components, models for 3D printing and laser cutting projects. Finally, VT5 and VT6 guide the user with a GUI developed for the application of BEST methods, step by step, i.e., from download to installation, also suggesting how to solve possible installation problems. An open-source instrumentation package for an intensive soil hydraulic characterization, an automatic infiltrometer-mounting tutorial, a walkthrough on how assembling an Arduino data logger, were shown in the VTs 7-9. Links to free tools to analyze the data for BEST method using: i) an automatic analysis of multiple infiltration experiments using Scilab coded by Lassabatere et al. (2013) and ii) an automatic analysis of multiple infiltration experiments using Excel and Visual Basic coded by Di Prima (2013), were shared. Worksheets to apply SFH, TSBI and SSBI were also shared (Table S1).

\section{CONCLUSIONS}

This review paper has described some of the most promising methods for saturated soil hydraulic conductivity estimation (SFH and SBI) and a procedure for a complete soil hydraulic characterisation, i.e., hydraulic conductivity function and water retention curve (BEST method). For these methods, some free tools were shared in order to both simplify their application to the agro-environmental applications and spread the techniques towards non-specialized users in soil science.

Analysis of literature suggests that discussed methods may be considered as a good compromise between measurement reliability, applicative simplicity and need for repeated sampling in space and time. Indeed, water infiltration techniques are easy to conduct and do not require intensive gears. Such advantages explain the great development and spread of these techniques around the world (Rahmati et al., 2018). However, BEST needs to be validated for some types of soils, including organic and gravel soils, or soils with macropores (AnguloJaramillo et al., 2019). Recently, the extension of BEST methods to dual permeability soils (e.g., soils with macropores or fractures) was proposed with a new algorithm, named BEST2K (Lassabatere et al., 2019a). BEST-2K method intends to characterize the full set of hydraulic parameters for both the matrix and the macropore compartments, making use of tension infiltrometer experiments for the activation of the matrix only and of the Beerkan experiments for the activation of both the matrix and the macropore network. Also, new approaches were proposed for the acquisition of several runs at the same time and the improvement of the statistical treatment of the data (Lassabatere et al., 2019b). The development of easy, robust, and relatively inexpensive methods for soil hydraulic characterization is an open topic in soil sciences. 
Acknowledgement. This work was supported through i) the "Sperimentazione produzione gessi di defecazione in linea depuratori di Barletta e Foggia e loro utilizzo in Puglia - Progetto RONSAS", ii) the "fondo di Ateneo per la ricerca 2020" dell'Università degli Studi di Sassari, iii) the "Programma Operativo Nazionale (PON) Ricerca e Innovazione 2014-2020 (Linea 1 - Mobilità dei ricercatori, AIM1853149, CUP: J54I18000120001) funded by the European Regional Development Fund (ERDF) and the Italian Ministry of Education, University and Research (MIUR), iv) the INFILTRON Project (ANR-17-CE04-0010, Package for assessing infiltration \& filtration functions of urban soils in stormwater management; https://infiltron.org/) funded by the French National Research Agency (ANR) and v) the PRIMA Fundation, call 2019-Section 1-GA n.1912 "Research-based participatory approaches for adopting Conservation Agriculture in the Mediterranean AreaCAMA" project, vi) AgriDigit-Agromodelli Project (DM n. 36502 of 20/12/2018), funded by the Italian Ministry of Agricultural, Food and Forestry Policies and Tourism.

\section{REFERENCES}

Agnese, C., Bagarello, V., Baiamonte, G., Iovino, M., 2011. Comparing physical quality of forest and pasture soils in a Sicilian watershed. Soil Sci. Soc. Am. J., 75, 1958-1970.

Aiello, R., Bagarello, V., Barbagallo, S., Consoli, S., Di Prima, S., Giordano, G., Iovino, M., 2014. An assessment of the Beerkan method for determining the hydraulic properties of a sandy loam soil. Geoderma, 235-236, 300-307.

Alagna, V., Bagarello, V., Di Prima, S., Giordano, G., Iovino, M., 2013. A simple field method to measure the hydrodynamic properties of soil surface crust. J. Agric. Eng., 44, 7479 .

Alagna, V., Bagarello, V., Di Prima, S., Iovino, M., 2016. Determining hydraulic properties of a loam soil by alternative infiltrometer techniques. Hydrol. Process., 30, 263-275.

Alagna, V., Bagarello, V., Di Prima, S., Guaitoli, F., Iovino, M., Keesstra, S., Cerdà, A., 2019. Using Beerkan experiments to estimate hydraulic conductivity of a crusted loamy soil in a Mediterranean vineyard. J. Hydrol. Hydromech., 67, 2, 1-10.

Angulo-Jaramillo, R., Bagarello, V., Iovino, M., Lassabatere, L., 2016. Infiltration Measurements for Soil Hydraulic Characterization. Springer International Publishing, Switzerland (ISBN 978-3-319-31786-1, 978-3-319-31788-5 (eBook) 386 pp.). http://dx.doi.org/10.1007/978-3-319-31788-5

Angulo-Jaramillo, R., Bagarello, V., Di Prima, S., Gosset, A., Iovino, M., Lassabatere, L., 2019. Beerkan Estimation of Soil Transfer parameters (BEST) across soils and scales. J. Hydrol., 576 , 239-261. https://doi.org/10.1016/j.jhydrol.2019.06.007

Armenise, E., Simmons, R.W., Ahn, S., Garbout, A., Doerr, S.H., Mooney, S.J., et al., 2018. Soil seal development under simulated rainfall: Structural, physical and hydrological dynamics. J. Hydrol., 556, 211-219.

Assouline, S., Mualem, Y., 2002. Infiltration during soil sealing: the effect of areal het- erogeneity of soil hydraulic properties. Water Resour. Res. 38, 1286.

Azam, M.G., Zoebisch, M.A., Wickramarachchi, K.S., 2008. Effects of cropping systems on selected soil structural properties and crop yields in the Lam phra phloeng WatershedNortheast Thailand. Journal of Agronomy, 7, 56-62.

Azam, M. G., Zoebisch, M.A., Wickramarachchi, K.S., Ranamukarachchi, S.L., 2009. Site-specific soil hydraulic quality index to describe the essential conditions for the optimum soil water regime. Can. J. Soil Sci., 89, 645-656.

Bagarello, V., Sgroi, A., 2007. Using the simplified falling head technique to detect temporal changes in field-saturated hydraulic conductivity at the surface of a sandy loam soil. Soil and Till. Res., 94, 283-294.

Bagarello, V., Iovino, M., Elrick, D.E., 2004. A simplified falling-head technique for rapid determination of fieldsaturated hydraulic conductivity. Soil Sci. Soc. Am. J., 68, 66-73.

Bagarello, V., Elrick, D.E., Iovino, M., Sgroi, A., 2006. A laboratory analysis of falling head infiltration procedures for estimating the hydraulic conductivity of soils. Geoderma, $135,322-334$.

Bagarello, V., Castellini, M., Iovino, M., Sgroi, A., 2010a. Testing the concentric-disk tension infiltrometer for field measurements of soil hydraulic conductivity. Geoderma 158, 427-435.

Bagarello, V., Di Stefano, C., Ferro, V., Iovino, M., Sgroi, A., 2010b. Physical and hydraulic characterization of a clay soil at the plot scale. J. Hydrol., 387, 54-64.

Bagarello, V., Di Prima, S., Iovino, M., Provenzano, G., Sgroi, A., 2011. Testing different approaches to characterize Burundian soils by the BEST procedure. Geoderma, 162, 141150.

Bagarello, V., D'Asaro, F., Iovino, M., 2012. A field assessment of the Simplified Falling Head technique to measure the saturated soil hydraulic conductivity. Geoderma, 187-188, 49-58.

Bagarello, V., Di Stefano, C., Iovino, M., Sgroi, A., 2013a. Using a transient infiltrometric technique for intensively sampling field-saturated hydraulic conductivity of a clay soil in two runoff plots. Hydrol. Process., 27, 3415-3423.

Bagarello, V., Castellini, M., Di Prima, S., Giordano, G., Iovino, M., 2013b. Testing a simplified approach to determine field saturated soil hydraulic conductivity. Procedia Environmental Sciences 19, 599-608.

Bagarello, V., Di Prima, S., Iovino, M., Provenzano, G., 2014a. Estimating field-saturated soil hydraulic conductivity by a simplified Beerkan infiltration experiment. Hydrol. Process., 28, 1095-1103.

Bagarello, V., Castellini, M., Di Prima, S., Iovino, M., 2014b. Soil hydraulic properties determined by infiltration experiments and different heights of water pouring. Geoderma, 213, 492-501.

Bagarello, V., Baiamonte, G., Castellini, M., Di Prima, S., Iovino, M., 2014c. A comparison between the single ring pressure infiltrometer and simplified falling head techniques. Hydrol. Process., 28, 4843-4853.

Bagarello, V., Di Prima, S., Giordano, G., Iovino, M., 2014d. A test of the Beerkan Estimation of Soil Transfer parameters (BEST) procedure. Geoderma, 221-222, 20-27.

Bagarello, V., Di Prima, S., Iovino, M., 2014e. Comparing alternative algorithms to analyze the Beerkan infiltration experiment. Soil Sci. Soc. Am. J., 78, 3, 724.

Bagarello, V., Di Prima, S., Iovino, M., 2017a. Estimating saturated soil hydraulic conductivity by the near steady-state phase of a Beerkan infiltration test. Geoderma, 303, 70-77.

Bagarello, V., Santis, A.D., Giordano, G., Iovino, M., 2017b. Source shape and data analysis procedure effects on hydraulic conductivity of a sandy-loam soil determined by ponding infiltration runs. J. Agric. Eng., 48, 71-80.

Bagarello, V., Cecere, N., Di Prima, S., Giordano, G., Iovino, M., 2017c. Height of water pouring effects on infiltration runs carried out in an initially wet sandy-loam soil. In: Chemical Engineering Transactions, Chemical Engineering 
Transactions. Italian Association of Chemical Engineering AIDIC, pp. 721-726. http://dx.doi.org/10.3303/cet1758121

Bagarello, V., Barca, E., Castellini, M., Iovino, M., Morbidelli, R., Saltalippi, C., Flammini, A., 2020. A plot-scale uncertainty analysis of saturated hydraulic conductivity of a clay soil. Journal of Hydrology, Article Number: 125694. https://doi.org/10.1016/j.jhydrol.2020.125694

Baiamonte, G., Bagarello, V., D'Asaro, F., Palmeri, V., 2017. Factors influencing point measurement of near-surface saturated soil hydraulic conductivity in a small Sicilian basin. Land Degrad. Develop., 28, 970-982.

Ben Slimene, E., Lassabatere, L., Šimůnek, J., Winiarski, T., Gourdon, R., 2017. The role of heterogeneous lithology in a glaciofluvial deposit on unsaturated preferential flow-a numerical study, Journal of Hydrology and Hydromechanics, 65, 3, 209-221. DOI: 10.1515/johh-2017-0004, 2017

Biddoccu, M., Ferraris, S., Opsi, F., Cavallo, E., 2016. Longterm monitoring of soil management effects on runoff and soil erosion in sloping vineyards in Alto Monferrato (NorthWest Italy). Soil Till. Res., 155, 176-189.

Biddoccu, M., Ferraris, S., Pitacco, A., Cavallo, E., 2017. Temporal variability of soil management effects on soil hydrological properties, runoff and erosion at the field scale in a hillslope vineyard, North-West Italy. Soil Till. Res., 165, 46-58.

Bien, L.B., Predelus, D., Lassabatere, L., Winiarski, T., Angulo-Jaramillo, R., 2013. Combined effect of infiltration, capillary barrier and sloping layered soil on flow and solute transfer in a heterogeneous lysimeter. J. Mod. Hydrol., 138153.

Bouarafa, S., Lassabatere, L., Lipeme-Kouyi, G., AnguloJaramillo, R., 2019. Hydrodynamic characterization of sustainable urban drainage systems (SuDS) by using Beerkan infiltration experiments. Water, 11, 4, Article Number: 660. DOI: $10.3390 /$ w 11040660

Braud, I., De Condappa, D., Soria, J.M., Haverkamp, R., Angulo-Jaramillo, R., Galle, S., et al., 2005. Use of scaled forms of the infiltration equation for the estimation of unsaturated soil hydraulics properties (the Beerkan method). Eur. J. Soil Sci., 56, 361-374.

Braud, I., Desprats, J.F., Ayral, P.A., Bouvier, C., Vandervaere, J.P., 2017. Mapping topsoil field-saturated hydraulic conductivity from point measurements using different methods. J. Hydrol. Hydromech., 65, 264-275.

Brooks, R.H., Corey, T., 1964. hydraulic properties of porous media. Hydrol. Paper 3, Colorado State University, Fort Collins.

Burdine, N.T., 1953. Relative permeability calculation from pore size distribution data. Petr. Trans. Am. Inst. Min. Metall. Eng., 198, 71-77.

Cannavo, P., Vidal-Beaudet, L., Béchet, B., Lassabatere, L., Charpentier, S., 2010. Spatial distribution of sediments and transfer properties in soils in a stormwater infiltration basin. J. Soils Sediments, 10, 8, 1499-1509.

Castellini, M., Pirastru, M., Niedda, M., Ventrella, D., 2013. Comparing physical quality of tilled and no-tilled soils in an almond orchard in southern Italy. Ital. J. Agron., 8, 149-157. DOI: $10.4081 /$ ija.2013.e20

Castellini, M., Giglio, L., Niedda, M., Palumbo, A.D., Ventrella, D., 2015. Impact of biochar addition on the physical and hydraulic properties of a clay soil. Soil Till. Res., 154, 1-13.

Castellini, M., Iovino, M., Pirastru, M., Niedda, M., Bagarello, V., 2016. Use of BEST procedure to assess soil physical quality in the Baratz Lake catchment (Sardinia, Italy). Soil Sci.
Soc. Am. J., 80, 742-755.

Castellini, M., Di Prima, S., Iovino, M., 2018. An assessment of the BEST procedure to estimate the soil water retention curve: a comparison with the evaporation method. Geoderma, 320, 82-94.

Castellini, M., Iovino, M., 2019. Pedotransfer functions for estimating soil water retention curve of Sicilian soils. Archives of Agronomy and Soil Science, 65, 10, 1401-1416. DOI: $10.1080 / 03650340.2019 .1566710$

Castellini, M., Fornaro, F., Garofalo, P., Giglio, L., Rinaldi, M., Ventrella, D., Vitti, C., Vonella, A.V. 2019a. Effects of notillage and conventional tillage on physical and hydraulic properties of fine textured soils under winter wheat. Water, 11, Article Number: 484. DOI: 10.3390/w11030484

Castellini, M., Stellacci, A.M., Tomaiuolo, M., Barca, E. 2019 b. Spatial variability of soil physical and hydraulic properties in a durum wheat field: an assessment by the BESTprocedure. Water, 11, Article Number: 1434. DOI: $10.3390 /$ w1 1071434

Castellini, M., Stellacci, A.M., Mastrangelo, M., Caputo, F., Manici, L.M., 2020a. Estimating the soil hydraulic functions of some olive orchards: Soil management implications for water saving in soils of Salento peninsula (southern Italy). Agronomy, 10, Article Number: 177. DOI: 10.3390/agronomy 10020177

Castellini, M., Vonella, A.V., Ventrella, D., Rinaldi, M., Baiamonte, G. 2020b. Determining soil hydraulic properties using infiltrometer techniques: an assessment of temporal variability in a long-term experiment under minimum- and no-tillage soil management. Sustainability, 12, Article Number: 5019. DOI: 10.3390/su12125019

Celentano, D., Rousseau, G.X., Engel, V.L., Zelarayan, M., Oliveira, E.C., Araujo, A.C.M., et al., 2017. Degradation of riparian forest affects soil properties and ecosystem services provision in eastern Amazon of Brazil. Land Degrad. Develop., 28, 482-493.

Cherubin, M.R., Karlen, D.L., Franco, A.L.C., Tormena, C.A., Cerri, C.E.P., Davies, C.A., et al., 2016. Soil physical quality response to sugarcane expansion in Brazil. Geoderma, 267, 156-168.

Chyba, J., Kroulík, M., Kristof, K., Misiewicz, P.A., Chaney, K., 2014. Influence of soilcompaction by farm machinery and livestock on water infiltration rate on grass-land. Agron. Res., 12, 59-64.

Chyba, J., Kroulik, M., Kristof, K., Misiewicz, P.A., 2017. The influence of agricultural traffic on soil infiltration rates. Agronomy Research, 15, 3, 664-673.

Ciollaro, G., Lamaddalena, N., 1998. Effect of tillage on the hydraulic properties of a vertic soil. J. Agric. Eng. Res., 71, 147-155.

Concialdi, P., Di Prima, S., Bhanderi, H.M., Stewart, R.D., Abou Najm, M.R., Lal Gaur, M., Angulo-Jaramillo, R., Lassabatere, L., 2020. An open-source instrumentation package for intensive soil hydraulic characterization. J. Hydrol., 582, Article Number 124492. https://doi.org/10.1016/j.jhydrol.2019.124492

Coutinho, A.P., Lassabatere, L., Montenegro, S., Antonino, A.C.D., Angulo-Jaramillo, R., Cabral, J.J.S.P., 2016. Hydraulic characterization and hydrological behaviour of a pilot permeable pavement in an urban centre, Brazil. Hydrol. Process., 30, 4242-4254. DOI: 10.1002/hyp.10985

Cullotta, S., Bagarello, V., Baiamonte, G., Gugliuzza, G., Iovino, M., La Mela Veca, D.S., et al., 2016. Comparing different methods to determine soil physical quality in a Mediterranean forest and pasture land. Soil Sci. Soc. Am. J., 80, 
$1038-1056$.

Dexter, A.R., 2004. Soil physical quality: Part I. Theory, effects of soil texture, density, and organic matter, and effects on root growth. Geoderma, 120, 201-214. https://doi.org/10.1016/J.GEODERMA.2003.09.004

Di Prima, S., 2013. Automatic analysis of multiple Beerkan infiltration experiments for soil Hydraulic Characterization In: Proc. 1st CIGR Inter-Regional Conference on Land and Water Challenges. p.127.

Di Prima, S., 2015. Automated single ring infiltrometer with a low-cost microcontroller circuit. Comput. Electron. Agric., 118, 390-395.

Di Prima, S., Lassabatere, L., Bagarello, V., Iovino, M., Angulo-Jaramillo, R., 2016. Testing a new automated single ring infiltrometer for Beerkan infiltration experiments. Geoderma, 262, 20-34.

Di Prima, S., Bagarello, V., Lassabatere, L., Angulo-Jaramillo, R., Bautista, I., Burguet, M., et al., 2017. Comparing Beerkan infiltration tests with rainfall simulation experiments for hydraulic characterization of a sandy-loam soil. Hydrol. Process., 31, 3520-3532.

Di Prima, S., Concialdi, P., Lassabatere, L., Angulo-Jaramillo, R., Pirastru, M., Cerda, A.; et al., 2018a. Laboratory testing of Beerkan infiltration experiments for assessing the role of soil sealing on water infiltration. Catena, 167, 373-384.

Di Prima, S., Rodrigo-Comino, J., Novara, A., Iovino, M., Pirastru, M., Keesstra, S., et al., 2018b. Soil physical quality of citrus orchards under tillage, herbicide, and organic managements. Pedosphere, 28, 463-477.

Di Prima, S., Castellini, M., Abou Najm, M.R., Stewart, R.D., Angulo-Jaramillo, R., Winiarski, T., Lassabatere, L., 2019. Experimental assessment of a new comprehensive model for single ring infiltration data. J. Hydrol., 573, 937-951. https://doi.org/10.1016/J.JHYDROL.2019.03.077

Di Prima, S., Stewart, R.D., Castellini, M., Bagarello, V., Abou Najm, M.R., Pirastru, M., Giadrossich, F., Iovino, M., Angulo-Jaramillo, R., Lassabatere, L., 2020a. Estimating the macroscopic capillary length from Beerkan infiltration experiments and its impact on saturated soil hydraulic conductivity predictions. Journal of Hydrology, 589, 125159. https://doi.org/10.1016/j.jhydrol.2020.125159

Di Prima, S., Winiarski, T., Angulo-Jaramillo, R., Stewart, R.D., Castellini, M., Abou Najm, M.R., Ventrella, D., Pirastru, M., Giadrossich, F., Capello, G., Biddoccu, M., Lassabatere, L., 2020b. Detecting infiltrated water and preferential flow pathways through time-lapse ground-penetrating radar surveys. Science of the Total Environment, Article Number: 138511. https://doi.org/10.1016/j.scitotenv.2020.138511

Donatelli, M., 2014. BioMA-biophysical model application framework. https://en.wikipedia.org/wiki/BioMA

Erban, T., Stehlik, M., Sopko B., Markovic M., Seifrtova M., Halesova T., et al., 2018. The different behaviors of glyphosate and AMPA in compost-amended soil. Chemosphere, 207, 78-83.

Elrick, D.E., Reynolds, W.D., 1992. Methods for analyzing constant-head well permeameter data. Soil Sci. Soc. Am. J., 56, 320-323.

Fernández-Gálvez, J., Pollacco, J., Lassabatere, L., AnguloJaramillo, R., Carrick, S., 2019. A general Beerkan Estimation of Soil Transfer parameters method predicting hydraulic parameters of any unimodal water retention and hydraulic conductivity curves: Application to the Kosugi soil hydraulic model without using particle size distribution data. Advances in Water Resources, 129, 118-130.

Ferrara, R.M., Mazza, G., Muschitiello, C., Castellini, M.,
Stellacci, A.M., Navarro, A., et al., 2017. Short-term effects of conversion to no-tillage on respiration and chemical physical properties of the soil: a case study in a wheat cropping system in semi-dry environment. Ital. J. Agrometeorol., 47-58. http://dx.doi.org/10.19199/2017.1.20385625.047

Fletcher, T.D., Shuster, W., Hunt, W.F., Ashley, R., Butler, D., Arthur, S., Trowsdale, S., Barraud, S., Semadeni-Davies, A., Bertrand-Krajewski, J.-L., et al., 2015. SUDS, LID, BMPs, WSUD and more-The evolution and application of terminology surrounding urban drainage. Urban Water Journal, 12, 525-542.

Gette-Bouvarot, M., Mermillod-Blondin, F., Angulo-Jaramillo, R., Delolme, C., Lemoine, D., Lassabatere, et al., 2014. Coupling hydraulic and biological measurements highlights the key influence of algal biofilm on infiltration basin performance. Ecohydrology, 7, 950-964.

Gonzalez-Merchan, C., Barraud, S., Bedell, J.P., 2014. Influence of spontaneous vegetation in stormwater infiltration system clogging. Environ. Sci. Pollut. Res., 21, 5419-5426.

Gonzalez-Sosa, E., Braud, I., Dehotin, J., Lassabatere, L., Angulo-Jaramillo, R., Lagouy, M., et al., 2010. Impact of land use on the hydraulic properties of the topsoil in a small French catchment. Hydrol. Process., 24, 2382-2399.

Goutaland, D., Winiarski, T., Lassabatere, L., Dubé, J.S., Angulo-Jaramillo, R., 2013. Sedimentary and hydraulic characterization of a heterogeneous glaciofluvial deposit: application to the modeling of unsaturated flow. Eng. Geol., 168, 127-139.

Grimaldi, M., Oszwald, J., Dolédec, S., Hurtado, del, M.P., de Souza Miranda, I., Arnauld de Sartre, X., et al. 2014. Ecosystem services of regulation and support in Amazonian pioneer fronts: searching for landscape drivers. Landscape Ecol., 29, 311-328.

Haverkamp, R., Ross, P.J., Smettem, K.R.J., Parlange, J.Y., 1994. Three-dimensional analysis of infiltration from the disc infiltrometer: 2 . Physically based infiltration equation. Water Resour. Res., 30, 2931-2935. https://doi.org/10.1029/94WR01788

Iserloh, T., Ries, J.B., Arnáez, J., Boix-Fayos, C., Butzen, V., Cerdà, A., et al., 2013. European small portable rainfall simulators: A comparison of rainfall characteristics. Catena, 110, 100-112. https://doi.org/10.1016/j.catena.2013.05.013

Jirků, V., Kodešová, R., Nikodem, A., Mühlhanselová, M., Žigová, A., 2013. Temporal variability of structure and hydraulic properties of top soilof three soil types. Geoderma, 204-205, 43-58. https://doi.org/10.1016/j.geoderma.2013.03.024

Kanso, T., Tedoldi, D., Gromaire, M., Ramier, D., Saad, M., Chebbo, G., 2018. Horizontal and vertical variability of soil hydraulic properties in roadside sustainable drainage systems (SuDS)-nature and implications for hydrological performance evaluation. Water, 10, Article Number: 987.

Keller, T., Sutter, J.A., Nisse, K., Rydberg, T., 2012. Using field measurement of saturated soil hydraulic conductivity to detect low-yielding zones in three Swedish fields. Soil Till. Res., 124, 68-77.

Khaledian, M.R., Mailhol, J.C., Ruelle, P., 2012. No-tillage impacts on soil hydraulic properties as compared with conventional tillage. Journal of Biological and Environmental Sciences, 6, 213-218.

Khaledian, M.R., Shabanpour, M., Alinia, H., 2016. Saturated hydraulic conductivity variation in a small garden under drip irrigation. Geosystem Engineering, 19, 266-274.

Khodaverdiloo, H., Cheraghabdal, H.K., Bagarello, V., Iovino, M., Asgarzadeh, H., Dashtaki, S.G., 2017. Ring diameter 
effects on determination of field-saturated hydraulic conductivity of different loam soils. Geoderma, 303, 60-69.

Klute, A., Dirksen, C., 1986. Hydraulic conductivity and diffusivity: laboratory methods. In: Klute, A. (Ed.): Methods of Soil Analysis. Part 1. Physical and Mineralogical Methods, 2nd ed. Agronomy, vol. 9. American Society of Agronomy, Madison, WI, pp. 687-734.

Kovář, S., Mašek, J., Novák, P., 2017. Comparison of tillage systems in terms of water infiltration into the soil during the autumn season. Agronomy Research, 15, 4, 1629-1635.

Lassabatere, L., Winiarski, T., Galvez-Cloutier, R., 2004. Retention of three heavy metals $(\mathrm{Zn}, \mathrm{Pb}$, and $\mathrm{Cd})$ in a calcareous soil controlled by the modification of flow with geotextiles. Environmental Science and Technology, 38, 4215-4221. https://doi.org/10.1021/es035029s

Lassabatere, L., Angulo-Jaramillo, R., Soria Ugalde, J.M., Cuenca, R., Braud, I., Haverkamp, R., 2006. Beerkan estimation of soil transfer parameters through infiltration experiments-BEST. Soil Sci. Soc. Am. J., 70, 521-532.

Lassabatere, L., Spadini, L., Delolme, C., Février, L., Galvez Cloutier, R., Winiarski, T., 2007. Concomitant Zn-Cd and $\mathrm{Pb}$ retention in a carbonated fluvio-glacial deposit under both static and dynamic conditions. Chemosphere, 69, 14991508. https://doi.org/10.1016/j.chemosphere.2007.04.053

Lassabatere, L., Peyrar, X., Angulo-Jaramillo, R., Simunek, J., 2009. Effects of the hydraulic conductivity of the matrix/macropore interface on cumulative infiltrations into dual-permeability media. AGU Fall Meeting Abstracts: A764.

Lassabatere, L., Angulo-Jaramillo, R., Goutaland, D., Letellier, L., Gaudet, J.P., Winiarski, T., Delolme, C., 2010. Effect of settlement of sediments on water infiltration in two urban infiltration basins. Geoderma, 156, 316-325.

Lassabatere, L., Angulo-Jaramillo, R., Yilmaz, D., Winiarski, T., 2013. BEST method: Characterization of soil unsaturated hydraulic properties. In: Caicedo et al. (Eds): Advances in Unsaturated Soils. CRC Press, London, pp. 527-532.

Lassabatére, L., Di Prima, S., Bouarafa, S., Iovino, M., Bagarello, V., Angulo-Jaramillo, R., 2019a. BEST-2D for characterizing dual-permeability unsaturated soils with ponded and tension infiltrometers. Vadose Zone Journal, 18, 1, 1-20. DOI: 10.2136/vzj2018.06.0124

Lassabatere, L., Di Prima, S., Angulo-Jaramillo, R., Keesstra, S., Salesa, D., 2019b. Beerkan multi-runs for characterizing water infiltration and spatial variability of soil hydraulic properties across scales. Hydrological Sciences Journal, 64, 2, 165-178. DOI: 10.1080/02626667.2018.1560448

Latorre, B., Moret-Fernández, D., Lassabatere, L., Rahmati M., López, M.V., Angulo-Jaramillo, R., et al., 2018. Influence of the $\beta$ parameter of the Haverkamp model on the transient soil water infiltration curve. J. Hydrol., 567, 22-229.

Leblanc, M., Tweed, S., Lyon, B.J., Bailey, J., Franklin, C.E., Harrington, G., Suckow, A., 2015. On the hydrology of the bauxite oases, Cape York Peninsula, Australia. J. Hydrol., $528,668-682$.

Lozano-Baez, S., Cooper, M., Ferraz, S., Ribeiro Rodrigues, R., Pirastru, M., Di Prima, S., 2018. Previous land use affects the recovery of soil hydraulic properties after forest restoration. Water, 10, 1-16.

Lozano-Baez, S.E., Cooper, M., Ferraz, S., Ribeiro Rodrigues, R., Castellini, M., Di Prima, S., 2019. Recovery of soil hydraulic properties for assisted passive and active restoration: Assessing historical land use and forest structure. Water, 11, 1, Article Number: 86. DOI: 10.3390/w11010086

Mubarak, I., Mailhol, J.C., Angulo-Jaramillo, R., Ruelle, P.,
Boivin, P., Khaledian, M., 2009a. Temporal variability in soil hydraulic properties under drip irrigation. Geoderma, $150,158-165$.

Mubarak, I., Mailhol, J.C., Angulo-Jaramillo, R., Bouarfa, S., Ruelle, P., 2009b. Effect of temporal variability in soil hydraulic properties on simulated water transfer under highfrequency drip irrigation. Agric. Water Manage., 96, 15471559.

Mubarak, I., Angulo-Jaramillo, R., Mailhol, J.C., Ruelle, P., Khaledian, M., Vauclin, M., 2010. Spatial analysis of soil surface hydraulic properties: is infiltration method dependent? Agric. Water Manage., 97, 1517-1526.

Nimmo, J.R., Schmidt, K.M., Perkins, K.S., Stock, J.D., 2009. Rapid measurement of field-saturated hydraulic conductivity for areal characterization. Vadose Zone Journal, 8, 142-149.

Philip, J.R., 1992. Falling head ponded infiltration. Water Resour. Res., 28, 2147-2148.

Pirastru, M., Niedda M., Castellini, M., 2014. Effects of maquis clearing on the properties of the soil and on the near-surface hydrological processes in a semi-arid Mediterranean environment. J. Agric. Eng., 45, 176-187.

Preti, F., Guastini, E., Penna, D., Dani, A., Cassiani, G., Boaga, J., et al., 2018. Conceptualization of water flow pathways in agricultural terraced landscapes. Land Degrad. Dev., 29, 651-662.

Rahmati, M., Weihermüller, L., Vanderborght, J., Pachepsky, Y.A., Mao, L., Sadeghi, S.H., et al., 2018. Development and analysis of Soil Water Infiltration Global Database. Earth System Science Data Discussions, 10, 1237-1263. https://doi.org/10.5194/essd-2018-11

Rallo, G., Provenzano, G., Castellini, M., Sirera, À.P., 2018. Application of EMI and FDR sensors to assess the fraction of transpirable soil water over an olive grove. Water, 10, Article Number: 168.

Rex, J., Dubé, S., Foord, V., 2013. Mountain pine beetles, salvage logging, and hydrologic change: Predicting wet ground areas. Water, 5, 443-461.

Reyes-Gómez, V.M., Olivas, O.V., Moreno, J.T.A., Sannwald, E.H., Rodríguez, A.R., 2015. Functional ecohydrological differences among native and exotic grassland covers in suburban landscapes of Chihuahua city, Mexico. Landscape and Urban Planning, 139, 54-62.

Reynolds, W.D., Elrick, D.E., 1985. In situ measurement of field-saturated hydraulic conductivity, sorptivity and the alpha-parameter using the Guelph permeameter. Soil Science, 140, 292-302.

Reynolds, W.D., Elrick, D.E., 1990. Ponded infiltration from a single ring: I. Analysis of steady flow. Soil Sci. Soc. Am. J., 54, 1233-1241.

Reynolds, W.D., Elrick, D.E., 2002. Pressure infiltrometer. In: Dane, J.H., Topp, G.C. (Eds.): Methods of Soil Analysis. Physical Methods. Part 4. 3rd ed. Soil Sci. Soc. Am., Madison, WI; pp. 826-836.

Reynolds, W.D., Lewis, J.K., 2012. A drive point application of the Guelph permeameter method for coarse-textured soils. Geoderma, 187-188, 59-66.

Šařec, P., Novak, P., 2017. Influence of manure and activators of organic matter biological transformation on selected soil physical properties of Modal Luvisol. Agronomy Research, $15,2,565-575$.

Scarabeli, I.G.R., Tormena, C.A., Favilla, H.S., Figueiredo, G.C., 2018. Field-saturated hydraulic conductivity measured by two techniques and at different sampling positions relative to maize-crop rows and interrows. Semina: Ciências Agrárias, Londrina, 9, 1, 403-410. 
Schwen, A., Bodner, G., Scholl, P., Buchan, G.D., Loiskandl, W., 2011. Temporal dnamics of soil hydraulic properties and the water-conducting porosity under different tillage. Soil and Tillage Research, 113, 2, 89-98.

Shelia, V., Šimunek, J., Boote, K., Hoogenbooom, G., 2018. Coupling DSSAT and HYDRUS-1D for simulations of soil water dynamics in the soil-plant-atmosphere system. J. Hydrol. Hydromech., 66, 232-245. https://doi.org/10.1515/johh2017-0055

Servadio, P., Bergonzoli, S., Beni, C., 2016. Soil tillage systems and wheat yield under climate change scenarios. Agronomy, 6, 43 .

Sidoli, P., Lassabatere, L., Angulo-Jaramillo, R., Baran, N., 2016. Experimental and modeling of the unsaturated transports of S-metolachlor and its metabolites in glaciofluvial vadose zone solids. J. Contam. Hydrol., 190, 1-14.

Siltecho, S., Hammecker, C., Sriboonlue, V., ClermontDauphin, C., Trelo-ges, V., Antonino, A.C.D., AnguloJaramillo, R., 2015. Use of field and laboratory methods for estimating unsaturated hydraulic properties under different land uses. Hydrol. Earth Syst. Sci., 19, 1193-1207.

Šimŭnek, J., van Genuchten, M.T., Šejna, M., 2016. Recent developments and applications of the HYDRUS computer software packages. Vadose Zone Journal, 15, 7, 1-25. https://doi.org/10.2136/vzj2016.04.0033

Smettem, K.R.J., Parlange, J.Y., Ross, P.J., Haverkamp, R., 1994. 3-Dimensional analysis of infiltration from the disc infiltrometer 1. A capillary-based theory. Water Resour. Res., 30, 2925-2929.

Souza, E.S., Antonino, A.C.D., Heck, R.J., Montenegro, S.M.G.L., Lima, J.R.S., Sampaio, E.V.S.B., et al., 2014. Effect of crusting on the physical and hydraulic properties of a soil cropped with castor beans (Ricinus communis L.) in the north eastern region of Brazil. Soil Till. Res., 141, $55-61$.

Souza, R., Souza, E., Netto, A.M., De Almeida, A.Q., J'unior, G.B., Silva, J.R.I., De Sousa Lima, J.R., Antonino, A.C.D., 2017. Assessment of the physical quality of a Fluvisol in the Brazilian semiarid region. Geoderma Reg., 10, 175-182.
Touma, J., Raclot, D., Al-Ali, Y., Zante, P., Hamrouni, H., Dridi, B., 2011. In situ determination of the soil surface crust hydraulic resistance. J. Hydrol., 403, 3-4, 253-260.

van Genuchten, M.T., 1980. A closed-form equation for predicting the hydraulic conductivity of unsaturated soils. Soil Sci. Soc. Am. J., 44, 5, 892-898.

Verbist, K.M.J., Cornelis, W.M., Torfs, S., Gabriels, D., 2013. Comparing methods to determine hydraulic conductivities on stony soils. Soil Sci. Soc. Am. J., 77, 1, 25-42.

White, I., Sully, M.J., 1987. Macroscopic and microscopic capillary length and time scales from field infiltration. Water Resour. Res., 23, 1514-1522. https://doi.org/10.1029/WR023i008p01514

Wu, L., Pan, L., Mitchell, J., Sanden, B., 1999. Measuring saturated hydraulic conductivity using a generalized solution for single-ring infiltrometers. Soil Sci. Soc. Am. J., 63, 788-792.

Xu, X., Lewis, C., Liu, W., Albertson, J.D., Kiely, G., 2012. Analysis of single ring infiltrometer data for soil hydraulic properties estimation: comparison of BEST and Wu methods. Agric. Water Manage., 107, 34-41.

Yang, J., Xu, X., Liu, M., Xu, C., Luo, W., Song, T., Du, H., Kiely, G., 2016. Effects of Napier grass management on soil hydrologic functions in a karst landscape, southwestern China. Soil Till. Res., 157, 83-92.

Yang, J., Xu, X., Liu, M., Xu, C., Zhang, Y., Luo, W., Zhang, R., Li, Z., Kiely, G., 2017. Effects of Grain for Green program on soil hydrologic functions in karst landscapes, southwestern China. Agric. Ecosyst. Environ., 247, 120-129.

Yilmaz, D., Lassabatere, L., Angulo-Jaramillo, R., Deneele, D., Legret, M., 2010. Hydrodynamic characterization of basic oxygen furnace slag through an adapted BEST method. Vadose Zone J., 9, 1, 107.

Yilmaz, D., Lassabatere, L., Deneele, D., Angulo-Jaramillo, R., Legret, M., 2013. Influence of carbonation on the microstructure and hydraulic properties of a basic oxygen furnace slag. Vadose Zone J., 12, 2. https://doi.org/10.2136/vzj2012.0121

Received 31 October 2020 Accepted 23 December 2020 


\section{SUPPLEMENTARY MATERIALS}

Table S1. Links to video tutorials for field infiltration experiments and data analysis.

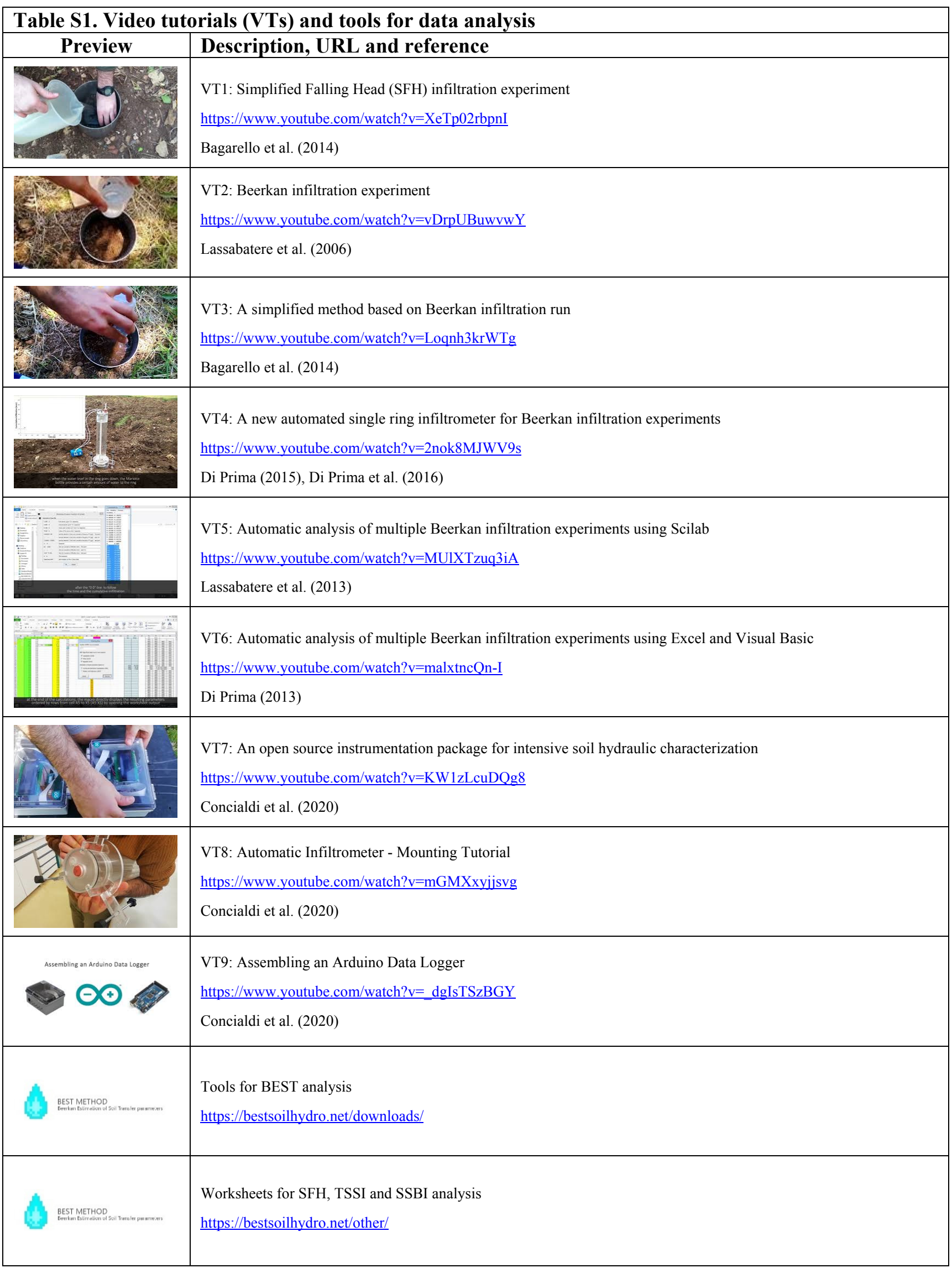

